\title{
A Harmonia segundo Aristóxeno de Tarento: comentários filosófico- epistemológicos sobre teoria musical grega
}

\author{
Paulo Eduardo de Barros Veiga ${ }^{1}$ \\ Universidade de São Paulo (USP) \\ pauloveiga@usp.br \\ Rubens Russomanno Ricciardi ${ }^{2}$ \\ Universidade de São Paulo (USP) \\ rubensricciardi@gmail.com
}




\section{Resumo}

Visando contribuir com os estudos de Harmonia, propõe-se um levantamento, com comentários, de expressões fundamentais da literatura musical grega, com base em Aristóxeno de Tarento (século IV a.C.). Sob essa proposta de análise semântica, também se procura perceber a organização de seu tratado de Harmonia, haja vista suas partes e uma metodologia. Por conseguinte, apontam-se alguns princípios filosóficos que norteiam a atividade musical, como a necessária

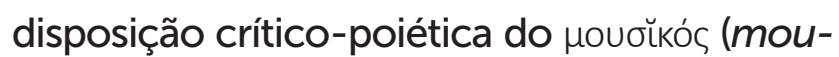
sikós) e o conhecimento da episteme musical. Também incluem-se breves comentários sobre a tradição da literatura musical em latim, expressa desde Martianus Capella e Fabius Fulgentius, aproximadamente no século $V$ d.C., até os teóricos mais tardios, com Sethus Calvisius e Blanchinus Veronensis, já no início dos séculos XVII e XVIII respectivamente, todos herdeiros de Aristóxeno e de seus epígonos, em menção a Aristides Quintiliano, Cleônides e Ptolomeu.

Palavras-chave: Teoria musical, Epistemologia, Harmonia, Aristóxeno de Tarento, Teoria musical medieval.

\section{Abstract}

Seeking to contribute to the studies of Harmony, we propose a data collection, with commentaries, of primary expressions of Greek musical literature, from Aristoxenus of Tarentum (4th century BC). Moreover, through that semantic analysis, we aim to understand the organization of his treatise on Harmony, highlighting its parts and methodology. Consequently, we point out some philosophical principles from musical thoughts, such as the

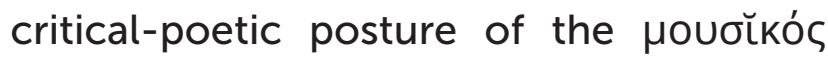
(mousikós) and the knowledge of the musical episteme. Thus, we include shorts comments on the tradition of the musical literature in Latin, found in authors such as Martianus Capella and Fabius Fulgentius, approximately in the 5th century AD, to later theorists, with Sethus Calvisius and Blanchinus Veronensis, already in the early 17 th and 18 th centuries respectively, all heirs of Aristoxenus and his epigones, in mention of Aristides Quintilian, Cleonides and Ptolemy.

Keywords: Music Theory, Epistemology, Harmony, Aristoxenus of Tarentum, Medieval Music Theory.

1 Pós-doutorando da Universidade de São Paulo, Faculdade de Filosofia, Ciências e Letras de Ribeirão Preto, Departamento de Música (USP-FFCLRP-DM). Membro do Núcleo de Pesquisa em Ciências da Performance em Música (NAP-CIPEM) e do Grupo Linceu - Visões da Antiguidade Clássica. Pesquisa realizada com apoio da FAPESP. Processo n²018/01418-2, Fundação de Amparo à Pesquisa do Estado de São Paulo (FAPESP). Endereço eletrônico: pauloveiga@usp.br.

2 Professor titular da Universidade de São Paulo, Faculdade de Filosofia, Ciências e Letras de Ribeirão Preto, Departamento de Música (USP-FFCLRP-DM). Coordenador do Núcleo de Pesquisa em Ciências da Performance em Música (NAP-CIPEM). Endereço eletrônico: rubensricciardi@gmail.com. 


\begin{abstract}
Eles se esquecem, porém, de que pertencem aos gregos, e não aos bárbaros, ${ }^{3}$ os feitos com os quais a filosofia começou, e não apenas, mas o próprio gênero humano. ${ }^{45}$
\end{abstract}

(Diógenes Laércio, Vitae philosophorum, I, 3, 1-3) ${ }^{6}$

\title{
INTRODUÇÃO
}

Com vistas à compreensão de parte do pensamento teórico-musical de Aristóxeno de Tarento (século IV a.C.), o músico primordial, o estudo ${ }^{7}$ divide-se em partes contíguas que tratam:

a) sobre Aristóxeno de Tarento, em um comentário biográfico muito breve;

b) sobre alguns princípios filosóficos em sua teoria, considerando o vir a ser um músico, o processo de escuta e a memória musical;

c) sobre a organização dos Elementos de Harmonia, haja vistas suas partes;

d) sobre noções de teoria musical, feito um levantamento semântico conciso;

e) sobre a expansão dos fundamentos de Aristóxeno, com destaque aos teóricos

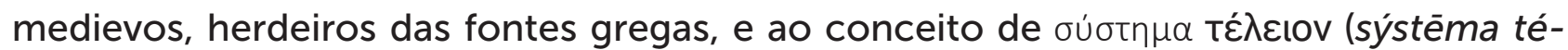
leion).

Sob essa disposição, apresenta-se um estudo de teor epistemológico que visa comentar alguns aspectos dos tratados musicais de Aristóxeno, percebendo a lógica de seu pensamento no processo de concepção de noções de teoria musical. Em nossa atividade de leitura, trabalha-se sempre com as fontes primárias, estabelecidas nas edições de Marquard (1868), Westphal (1883) e Macran (1902), em diálogo com especialistas, com destaque a Gibson (2005), dentre outras referências indicadas na bibliografia. ${ }^{8}$

O músico de Tarento, importante discípulo de Aristóteles, cunhou diversos conceitos que fundamentaram a tradição teórico-musical, continuados por seus epígonos,

3 Diógenes Laércio contradiz os autores que dizem que a filosofia não é grega, mas oriunda de outros povos, como os persas, babilônios, assírios, hindus, celtas, gauleses, fenícios, trácios, líbios ou egípcios.

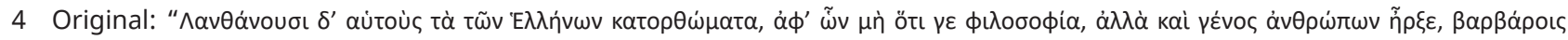

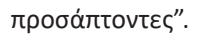

5 Todas as traduções são nossas, exceto quando indicado o nome do tradutor.

6 A forma de citação de autores antigos seguirá a praxe de área.

7 Neste artigo, visando atingir um público amplo, não familiarizado com o alfabeto grego, optou-se por transliterar algumas palavras da língua grega, somente em sua primeira ocorrência e sem repetição. Ademais, em se tratando de estudo filológico-epistemológico, a pesquisa exige preservar, ao máximo possível, as fontes primárias. Por essa razão, procurou-se tanto manter ambas as formas das palavras gregas (original e transliterada) quanto dispor as citações na língua original, seguida de nossa tradução. Dessa maneira, conserva-se o caráter da pesquisa sem restringir o público-alvo, quais sejam, os estudantes de música que desejam conhecer um pouco mais sobre os primórdios da harmonia.

8 Em cotejo, foi consultada a base de dados TLG, para as obras da Grécia antiga, a partir do programa digital $\Delta$ ıoývnৎ (Diogenes, em inglês), uma ferramenta de leitura e pesquisa de textos antigos. 
a citar, Cleônides, Ptolomeu e Aristides Quintiliano, além de outros pensadores da música, sem mencionar a Antiguidade tardia, a Idade Média e o Renascimento, com destaque a Martianus Capella, Cassiodorus, Boethius, Franchinus Gaffurius e Henricus Glareanus, ${ }^{9}$ dentre outros autores de expressão latina, com extensão ao século XVII e XVIII, com Sethus Calvisius e Blanchinus Veronensis. Mesmo após mais de vinte séculos, eles ainda expressam fundamentos diretamente estabelecidos por Aristóxeno.

Em resumo, considerando a importância da obra de Aristóxeno à música, ainda mais, com destaque ao processo de ordenação e de teorização do conhecimento musical, propõe-se, neste estudo, um comentário filológico de expansão epistemológica ${ }^{10}$ sobre o tratado de Harmonia, com destaque à divisão da teoria, à terminologia musical e ao processo de construção teórica. Em palavras mais breves, procurando perceber o modus faciendi de Aristóxeno na organização da episteme musical, sob uma análise de teor semântico-epistemológico, ressalte-se a consequência do pensamento grego ao conhecimento musical.

\section{SOBRE ARISTÓXENO, O MÚSICO PRIMORDIAL}

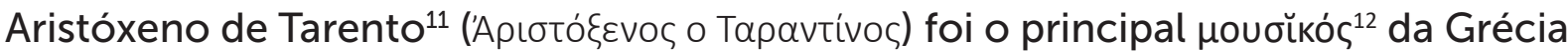
Antiga, aproximadamente no século IV a.C. Também filósofo, um profícuo historiador e um dos principais discípulos de Aristóteles, o Estagirita (384-322 a.C.), organizou o

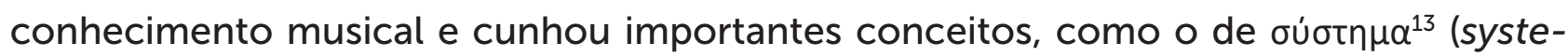
ma, em latim), que será tratado neste estudo. Em função da importância de seus textos, principalmente dos tratados de harmonia e ritmo, tornou-se a principal e mais fundamental referência de pensador da Música.

Entre comentadores e estudiosos da Antiguidade, tanto gregos (incluindo a Grécia romanizada), como Cleônides, Ptolomeu, Plutarco, Diógenes Laércio, Aristides Quintiliano, quanto romanos, como Cícero, Marciano Capela (já na Antiguidade tardia), sem excluir os pensadores medievais, como Boécio e Cassiodoro, Aristóxeno era tomado

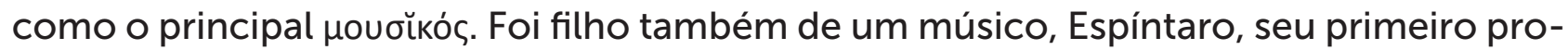

9 A fim de já sugerir a língua de produção do autor, optou-se por manter a versão latina dos nomes que se expressaram em latim. Assim, Martianus Capella, em vez de Marciano Capela.

10 O trabalho de levantamento lexical, estabelecimento semântico e descrição da estruturação do texto é de base filológica; já a expansão desses conceitos às diversas áreas do conhecimento, com destaque à História das Ciências (relação explicitada na última seção deste artigo), é de expressão epistemológica. Ambos, a serviço da Filosofia.

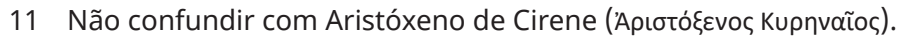

12 Mousikós. Utiliza-se o termo grego em função de seu sentido mais amplo e complexo sobre o que é o vir a ser um músico. Nesse viés, não se trata apenas do instrumentista, performático, quanto menos do curioso, mas do indivíduo multifário, que põe em conjunção o músico performático, o músico teórico, o músico poético e o músico filósofo.

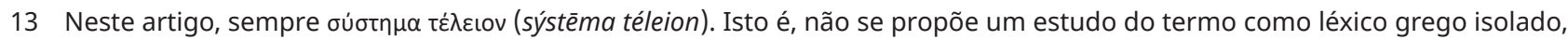

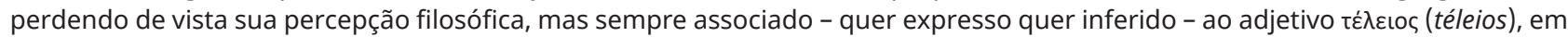
seu sentido específico, qual seja, "máximo, completo, íntegro". Em relação ao seu conteúdo semântico, é comum encontrar, atribuído a téleion, o sentido de "perfeito". No entanto, embora até usual, trata-se de uma concepção equivocada (CHAILLEY, 1960). 
fessor. Em seu percurso filosófico-musical, foi discípulo de importantes pensadores, tais quais Lámpro de Eritreia, o pitagórico Xenófilo e, principalmente, Aristóteles, o Estagirita.

Costuma-se dizer que Aristóxeno ofendera a seu último mestre, que estava já no final da vida, por ter escolhido Teófrasto, outro discípulo, para ser o sucessor de sua escola. Talvez Aristóxeno se considerasse o mais importante dos aristotélicos? Essa contenda entre discípulo e mestre é uma referência obscura na História, uma vez que não existe nenhuma declaração, de fato, de Aristóxeno contra Aristóteles (TRENDELENBURG, 1826). No entanto, Arístocles, segundo Eusébio (Praeparatio Evangelica, XV, 2; 791c), comenta que Aristóxeno nunca ofendera o mestre.

Mas quem acreditou no que Aristóxeno, o músico, estava dizendo em sua "Vida de Platão"? (F H G II 282, 33, 35). Diz que, enquanto Platão peregrinava, estando bem longe de casa, alguns estrangeiros colocaram-se contra ele, construindo um Perípato. Certamente supunham que se referia a Aristóteles, quando, na verdade, Aristóxeno sempre falou bem de Aristóteles. (Aristocles, Phil., f 2.22-26, grifos nossos)..$^{14}$

Aristóxeno deixou importantes obras das quais restaram, ainda incompletas, o seu

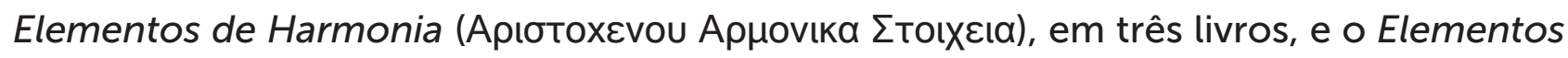

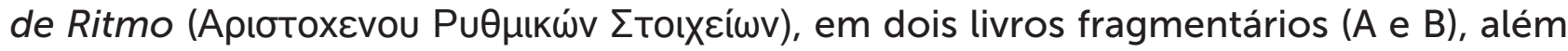
de outras obras bem mais fragmentárias. Comenta-se, ${ }^{15}$ no entanto, que tenha escrito muito sobre História, Filosofia e Educação, dentre outros assuntos de seu escopo.

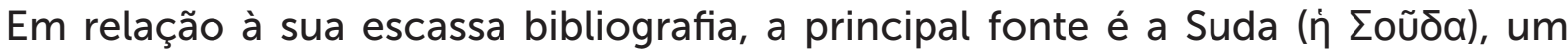
extenso léxico, de teor enciclopédico, com mais de trinta mil entradas, sobre os mais diversos assuntos e personagens. Nela encontra-se o verbete "Aristóxenos":

Aristóxeno: filho de Mnésio, ou então de Espíntaro, o músico é oriundo de Tarento, na Itália. Enquanto vivia em Mantineia [na Arcádia Grega], tornou-se um filósofo e com certeza não falhou em colocar-se à disposição da música. Foi discípulo de seu pai, de Lámpro de Eritreia, de Xenófilo, o pitagórico, e, por fim, de Aristóteles. Enquanto o seu mestre estava morrendo, Aristóxeno insultou-o, porque foi esquecido como sucessor de sua escola, perdendo para Teófrasto, embora tivesse muito maior reputação entre os discípulos de Aristóteles. Viveu durante o período de Alexandre e o tempo posterior, depois dos jogos olímpicos de número 111, sendo contemporâneo de Dicearco de Messênia [no Peloponeso]. Ele compôs obras sobre Música, Filosofia e História, além de obras de natureza pedagógica; os seus livros estão ao número de $453 .{ }^{16}$

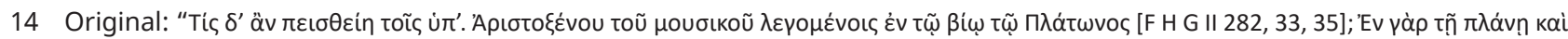

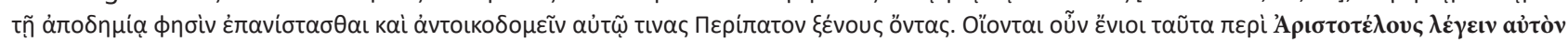

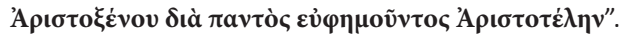

15 Vários pensadores, como Diógenes Laércio (Vitae Philosophorum), Aristides Quintiliano (Пعрí Mouбıкñৎ), Ateneus (Deipnosophistae), dentre outros escritores, sejam gregos, sejam latinos, comentam sobre Aristóxeno de Tarento, não apenas sobre sua obra teórico-musical, mas também histórica, que deveria ter sido muito extensa.

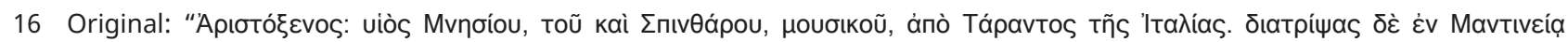


Tendo o reconhecimento de que Aristóxeno tenha sido não somente um instrumentista ou um filósofo, mas, acima de tudo, um uouб̌̌́ós, foi, senão, o pensador primordial da arte da música. Para ele, não bastava tocar um instrumento, mesmo que

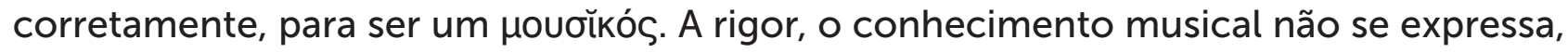
necessariamente, com um instrumento musical em mãos. O requisito fundamental é ter ciência dessa arte em sua abstração e percepção, mediada pela inteligência empática,

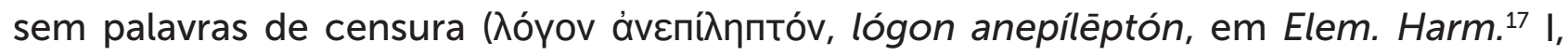
21.14), que é o desejo de querer ouvir e aprender em primeiro lugar, em postura humilde.

É imprescindível, portanto, a quem quer ser músico dominar a episteme musical

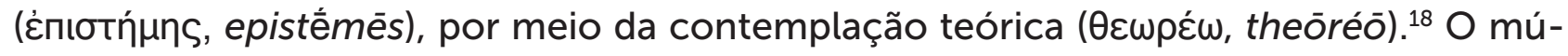
sico, pois, deve assimilar tudo aquilo que se refere à música, sendo esta sua condição:

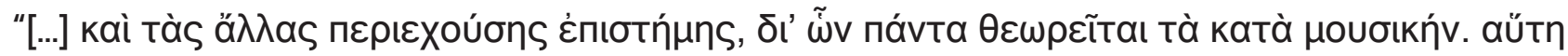

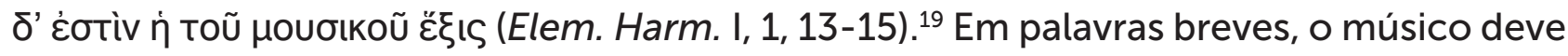
ter o conhecimento intelectual e sensorial dos assuntos relacionados à música - tais quais a Harmonia, a Melodia e o Ritmo, dentre outros tópicos referentes à episteme musical.

Em síntese, o conhecimento musical completo, haja vista a faculdade de conhecer

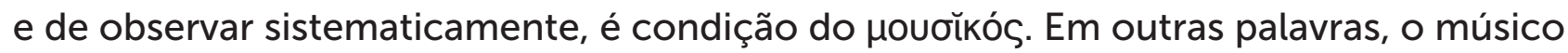
é quem domina a ciência da música. Nesse sentido, o estudo de Harmonia seria uma

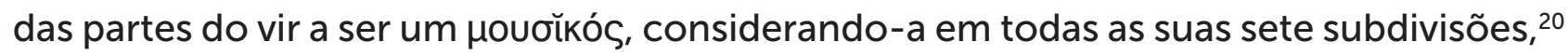
assim resumidas em: gêneros, intervalos, notas, escalas, tonalidades, modulações e melodias.

Em resumo, Aristóxeno deixa claro, em seus tratados, que conhecer muito bem

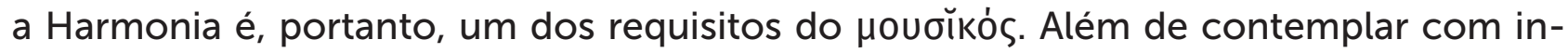
teligência a natureza da arte musical, deve-se ter a sagacidade de aprender a músi-

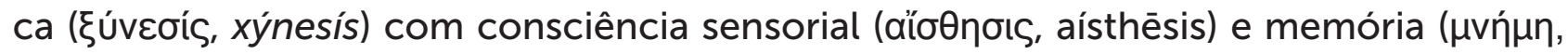
mnếmē).

Por conseguinte, quem reúne os sons que se tornam melodia, tanto pela audição quanto pela inteligência, é capaz de distinguir o movimento que é produzido su-

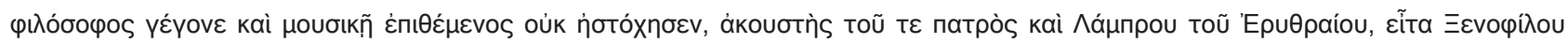

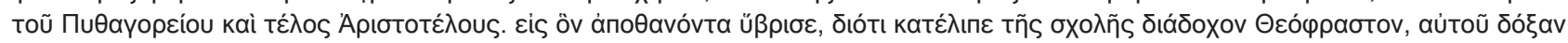

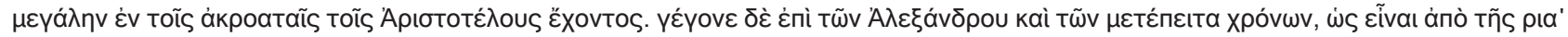

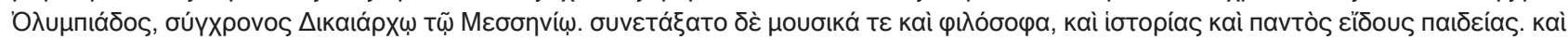

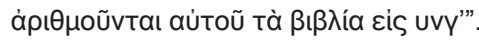

17 Para evitar repetições, não se constará o nome de Aristóxeno nas referências aos Elementos de Harmonia e aos Elementos de Ritmo, já bem esclarecida a autoria.

18 Adota-se a primeira pessoa do singular do presente do indicativo como padrão de referência de verbos gregos e latinos, conforme praxe.

19 Mais literalmente: “[...] mas também o conhecimento daqueles assuntos a serem assimilados, por meio dos quais se observa tudo aquilo relativo à música. Esta é, pois, a condição do músico".

20 Tópico tratado em seção posterior (conferir Quadro 1).
} 
cessivamente a vir a ser a melodia, como partes futuras da música. Em relação a isso, é dupla a faculdade da música: a percepção e também a memória. Portanto é necessário perceber, de um lado, o que virá a ser, guardando na memória o que já passou. Definitivamente não há, porém, outra forma de compreender a música. (Elem. Harm., II, 48,11-18). ${ }^{21}$

O músico, por excelência, domina, principalmente e não exclusivamente, o conhecimento sobre a harmonia e sobre o ritmo, o qual cabe também ao teatro, à escultura, à dança, à literatura, dentre outras artes, porque elas se valem, de alguma forma, da

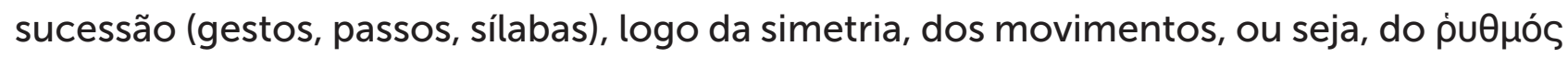
(rhythmós), como fenômeno especial do tempo (xpóvos, khrónos). ${ }^{22}$ No entanto, é sempre necessário, por questão de fulcro teórico, restringirem-se os conceitos abordados e as reflexões feitas ao domínio estritamente musical, tendo em vista que tempo é uma categoria primordial e muito genérica; e ritmo, geral às artes.

Nos Elementos de Ritmo, Aristóxeno comenta sobre a ampla natureza do ritmo, sendo necessário, por essa razão, ater-se ao sistema musical. Assim, afirma:

O ritmo possui, de fato, inúmeras naturezas. Já foi falado, anteriormente, sobre a espécie de cada um, sobre os motivos por meio dos quais tiveram mesmos nomes e sobre em que se baseia cada um. Mas agora devemos falar sobre o ritmo estabelecido especificamente na música. (Elem. Rit., II, 17.3-7). ${ }^{23}$

Consciente das semelhanças nominais e das partes da ciência musical, sob uma rigorosa percepção metodológica do objeto de estudo e uma inteligência sensorial, o músico, portanto, é capaz de compreender a natureza dessa arte, em específico. Logo,

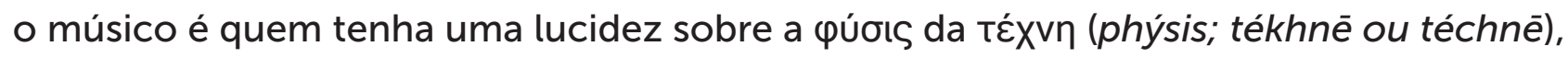
isto é, a natureza dessa arte.

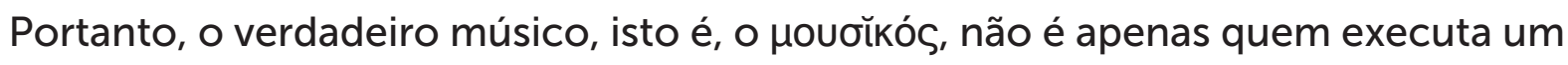
instrumento, mesmo que habilmente, quanto menos de modo curioso. Assim, como não existe um matemático que desconheça a natureza dos números, ou um dançarino sem rítmica, não existe um músico que ignore a natureza dos sons, suas regras, partes e princípios. Novamente, não se trata jamais do curioso que executa um instrumento ingenuamente, mas do artista que, tal qual um cientista e um filósofo, se coloca em busca do conhecimento e da percepção unidos pela inteligência, em que a clareza sobre a natureza da arte não pode ser embasada em opinião. Logo, é princípio do vir a ser

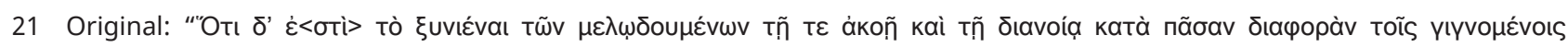

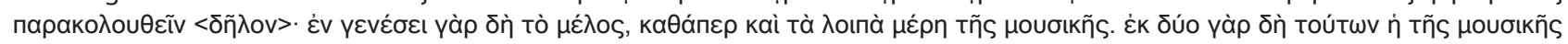

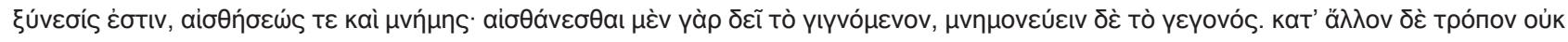

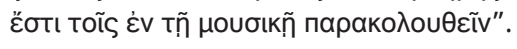

22 Ou chrónos (assim como em outras ocorrências de $\mathrm{X}$ ).

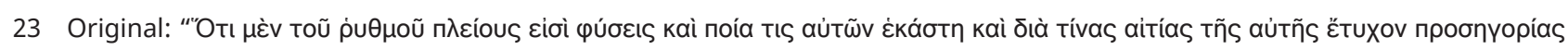

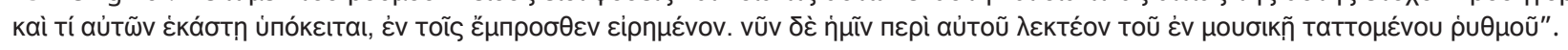




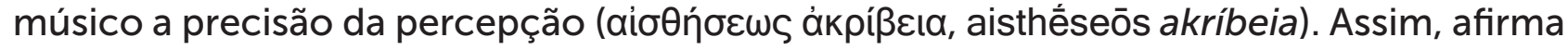
o músico: "Já ao músico, é de sua condição - tendo-a de origem - a precisão do ouvido24" (Elem. Harm. II, 42.21-22, grifos nossos).

Nesse sentido, sob liberdade metafórica, a arte confia aos artistas que deseja a configuração poética, sem contrapor prática e teoria, ${ }^{25}$ não obstante a linguagem. $O$ músico, poeta e artesão, ${ }^{26}$ vale-se, pois, da postura filosófica e da noínбıc (poíēsis), sob contemplação intelectual associada a uma percepção precisa dos sentidos, sempre atentos. Em uma metáfora permissiva, o músico deixa-se encantar pela noínбıc, invenção artística em superação da linguagem, tal qual um "Hesíodo" se deixe conduzir primeiramente pelas Musas.

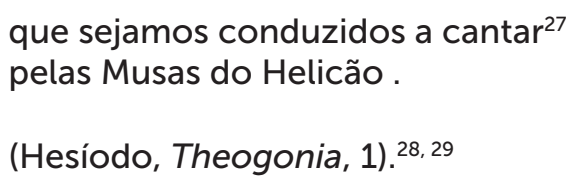

Extrapolando o pensamento de Aristóxeno, esta antiga metáfora, em paralelo literário, pode sintetizar poeticamente os requisitos do artista, que sabe ouvir e ver, muito

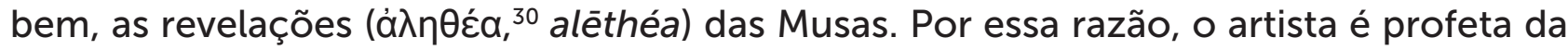

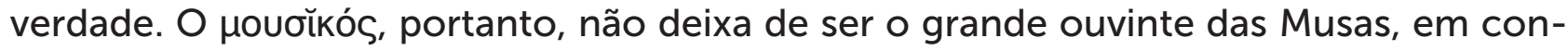
templação intelectual, inteligência empática e sensorialidade precisa.

\section{A HARMONIA SEGUNDO ARISTÓXENO}

[...] por haver uma certa ordem maravilhosa que pertence à natureza harmoniosa em geral [...]. (Elem. Harm. II, 53.6-7, grifos nossos). ${ }^{31}$

Como se sabe, Aristóxeno não escreveu seus tratados ex nihil e não foi o primeiro ou o mais antigo teórico de música, sendo, na verdade, discípulo de muitos pensadores da aritmética, como Pitágoras, quem chegou a conhecer. No entanto, foi ele quem sistematizou, de fato, o estudo de música, sem excluir a percepção. O tarentino, obstinado

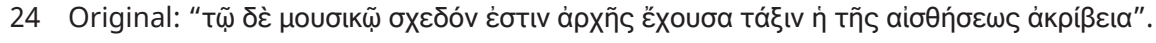

25 Não concebemos ambos os termos, teoria e prática, como categorias contrárias, distintas ou complementares, senão sob uma relação indissociável e solidária.

26 Note-se a produção ou a invenção artística a partir de um artesanato. Ademais, não se restringe a noção de poesia exclusivamente à atividade verbal. Mais amplo e complexo, considera-se, pois, o fenômeno artístico.

27 Montanha da Grécia.

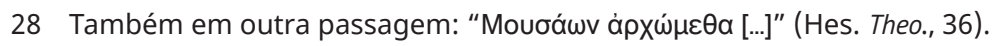

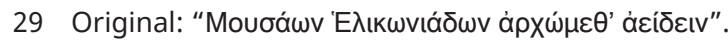

30 Hesíodo, Teogonia, 28.

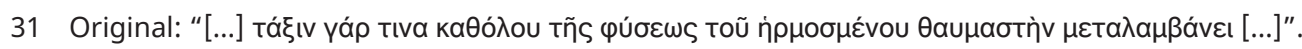


pela sistematização epistêmica, cunhou importantes conceitos para estudar a natureza musical, a ponto de tornar-se o "pai da musicologia", pelo modo original e metodológico com que organizou o conhecimento filosófico musical, sob esteira aristotélica.

Aristóxeno, como mencionado, recebeu influências da escola pitagórica, que foi responsável, dentre outras questões, por estabelecer razões numéricas no estudo dos intervalos, a fim de explicar sobre a sua natureza. Além disso, ele conviveu com diversos filósofos atenienses que expunham seus pensamentos sobre música, ora a partir da teoria mística da Harmonia das Esferas, ${ }^{32}$ ora à luz de novas tentativas de teorização. Naturalmente, também foi influenciado por seu pai, o músico Espíntaro, e por outros mestres. Mas a sua principal influência foi, sem dúvida, Aristóteles.

Em seus tratados, como chegaram até nós, Aristóxeno cita raros teóricos, para comentar, na verdade, sobre suas tentativas ou seus equívocos.

[...] no entanto, ninguém até hoje se preocupou em delimitar cuidadosamente a diferença de cada uma das notas. E, decerto, sem essa diferenciação, será muito difícil falar sobre elas. Por isso, é preciso não aceitar o que Laso e também os discípulos de Epígono supuseram, a quem extensão confundia-se com nota, a fim de que falemos com um pouco mais de rigor. (Elem. Harm., I, 7.16-22). ${ }^{33}$

Nessa passagem, por exemplo, ele comenta sobre a importância de delimitar

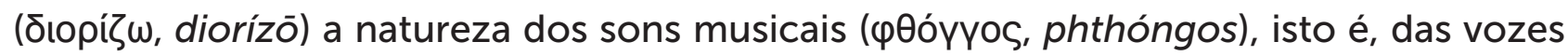
ou das notas de um instrumento musical. Afirma ainda que, caso se deseje ter precisão de sentido, será necessário evitar os equívocos de Laso de Hermíone ${ }^{34}$ e de alguns pensadores da escola de Epígono de Ambracia, ambos contemporâneos que, segundo Aris-

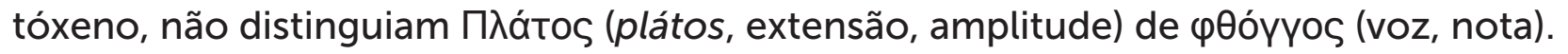

Erátocles, um teórico musical do século $V$ a.C., no entanto, como cita Aristóxeno, ${ }^{35}$ foi o único, de todos os predecessores, que tentou desenvolver uma das partes do estudo de Harmonia, referente à natureza das escalas, porém, segundo o epígono de Aristóteles, de modo falho e sem demonstração. Mais do que isso, obteve resultados falsos, tendo falhado no estudo da percepção (aǐoӨnoıc). Pode-se notar a importância que o discípulo de Aristóteles dava à demonstração e à percepção como fundamento

32 A Harmonia das Esferas - relacionando distintas áreas, desde a matemática, a astronomia, a astrologia, a música, bem como expressando-se por meio de metáforas, símbolos, mitos e histórias cosmogônicas, de pendor etiológico - procurava compreender o fenômeno de criação demiúrgica, sobre a natureza das coisas, principalmente da relação numérica entre os astros, suas proporções, em busca de uma relação musical cósmica, entre planetas, que produzissem notas e intervalos, em processos de divisibilidade e imanência (conferir Platão, Timeus, 35.a.1 - 37c.5). Trata-se de um encontro místico-metafórico entre astronomia e música, principalmente.

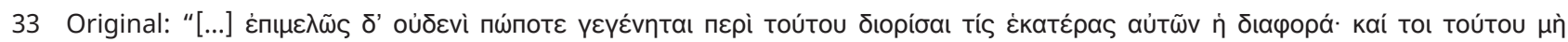

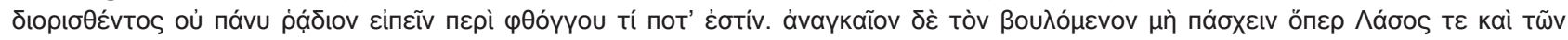

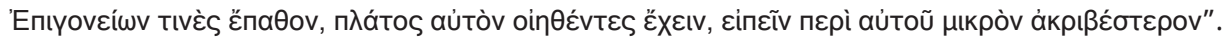

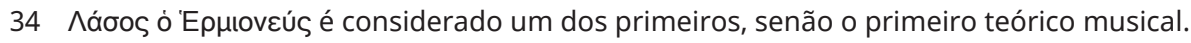

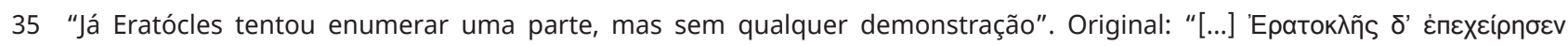

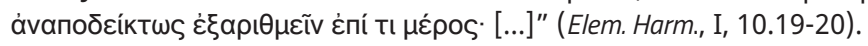


metodológico do estudo teórico de música, mesmo sem a materialidade do canto ou do instrumento. Ou seja, embora o assunto seja tratado de forma abstrata, isto é, pelo

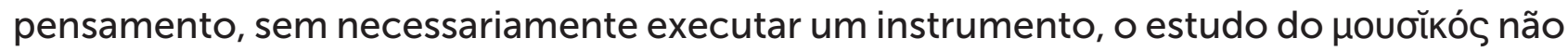
deve prescindir nem de argumentos verdadeiros, nem do senso estético, isto é, a razão sob a luz da sensorialidade.

O músico também menciona Platão e Aristóteles, logo no início do segundo livro (II, 39.4 - 40.13), desaconselhando o método do primeiro e defendendo o segundo. Ou seja, nesse ponto, há um comentário com que o discípulo enaltece a metodologia de Aristóteles e critica a organização de Platão. No caso, este, também de nome Arístocles, divulgou uma palestra sobre as coisas boas (áyaӨós, ${ }^{36}$ agathós), a que foram os interes-

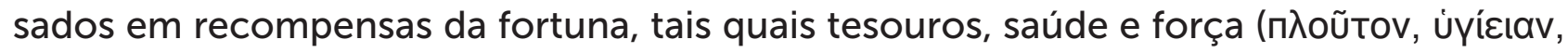
íđxúv, ploûton, hygíeian, iskhýn ou ischýn). No entanto, Platão palestrou sobre ciência, números, geometria e astronomia, dentre outros assuntos de seu escopo, que considerava serem as verdadeiras fortunas do homem. O resultado foi o fracasso da exposição em função do público, de índole incompatível com o palestrante. Por isso, Aristóxeno elogia o modo como procede Aristóteles, sempre informando, primeiramente, o assunto de que tratará e a disposição do estudo. A Aristóxeno, portanto, é sempre desejável a informação preparatória, demonstrando preferência à organização e à metodologia aristotélicas em detrimento da ironia platônica.

Em função dessa postura que preze o rigor metodológico, os tratados de Aristóxeno são organizados em partes muito bem-definidas, com propostas claras e específicas, sempre introduzindo o assunto e, depois, sintetizando ou recuperando os passos. Em cada uma delas, preza-se a clareza na distinção entre categorias e subcategorias, diferenciando-as. Essa proposta, portanto, teoriza o objeto de estudo, muito bem-definido, por meio do estabelecimento de conceitos e subconceitos.

Assim, do córpus analisado pelo grego, qual seja, a episteme musical, mais especificamente a parte da Harmonia, depreendem-se elementos primordiais, principalmente por dedução, tendo clareza em cada tarefa a ser cumprida para a compreensão do todo. Feito isso, Aristóxeno analisa cada elemento, a fim de entender-lhe a natureza e, se necessário, a quantidade ou os valores numéricos (ápı $\theta$ uós, arithmós). Note-se ainda que, frequentemente, ele procura distinguir conceitos emparelháveis (por exemplo, diferença entre canto e fala, entre afinação e altura, entre grave e agudo etc.). Em cada elemento, pode-se depreender subelementos, repetindo o mesmo processo de análise, sob padrão. Em síntese, essa organização visa compreender a natureza da episteme musical, partindo da natureza dos gêneros à construção da melodia (monódica), a

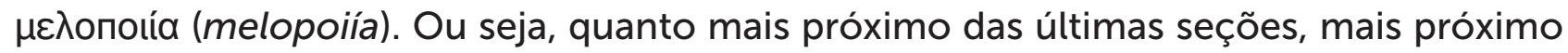
do estudo do fenômeno melódico.

A Harmonia mais especificamente está dividida em sete partes, conforme o quadro a seguir. Nele é possível identificar cinco colunas, descritas da seguinte maneira:

1ạ coluna: indica, em algarismo romano, a numeração das sete partes que constituem os assuntos mais gerais;

36 Trata-se de uma ironia semântica, já que áyäós pode qualificar as coisas boas, tanto em sentido intelectual quanto em sentido financeiro, qual seja, a riqueza material. 
2a coluna: aponta o assunto de que trata a parte, em apenas uma única palavra (as correspondências latinas foram retiradas de Fulgentius ${ }^{37}$ ), com breve comentário; 3a coluna: apresentam-se os elementos primordiais da parte, valendo-se da sequência de

línguas: grego, latim e português;

4므 coluna: descrevem-se os objetivos ${ }^{38}$ mais gerais da parte;

5a coluna: se necessário, incluem-se observações sobre a parte.

Assim, por meio dessa descrição, procura-se expor a organização dos Elementos de Harmonia. Em acréscimo, é necessário considerar o caráter didático do quadro, sem pretensão de fôlego, haja vista as distintas tarefas e discussões em cada seção ou parte. Segue o quadro:

37 "Assim, a música divide-se em sete partes, quais sejam, os gêneros, os intervalos, as escalas, as notas, os tons, as modulações e as melodias". Original: "Habet igitur musica partes septem, id est genera, diastemata, systemata, ptongos, tonos, metabolas et melopias" (Fulgentius, Mitol., III, 128, 19-20).

38 Aristóxeno tinha o hábito de expor os objetivos de cada assunto antes de iniciar a discussão. 


\begin{tabular}{|c|c|c|c|c|}
\hline & Partes & $\begin{array}{l}\text { Elementos primor- } \\
\text { diais }\end{array}$ & Objetivos & Observação \\
\hline I & $\begin{array}{l}\text { Gêneros (gene- } \\
\text { ra) } \\
\text { A primeira parte } \\
\text { do estudo de Har- } \\
\text { monia. }{ }^{30}\end{array}$ & $\begin{array}{l}\text { Yévos, } \\
\text { genus, } \\
\text { gênero. }\end{array}$ & 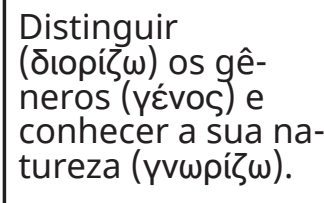 & \\
\hline II & 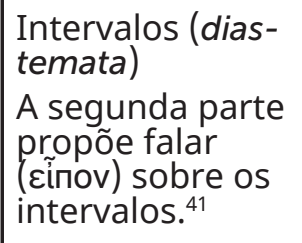 & 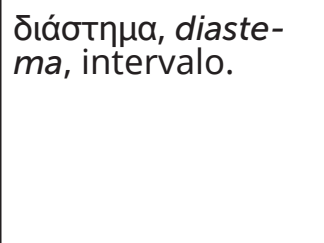 & $\begin{array}{l}\text { Conhecer a natu- } \\
\text { reza dos interva- } \\
\text { los, distinguindo- } \\
\text {-os da forma mais } \\
\text { completa possível. }\end{array}$ & \\
\hline III & $\begin{array}{l}\text { Notas musicais } \\
\text { (ptongos) } \\
\text { A terceira parte } \\
\text { trata das notas } \\
\text { do modo mais } \\
\text { completo possí- } \\
\text { vel. }{ }^{42}\end{array}$ & $\begin{array}{l}\varphi \theta \text { yyos, pton- } \\
\text { gus } 43 \text { vox, nota. }\end{array}$ & $\begin{array}{l}\text { Conhecer a na- } \\
\text { tureza das notas, } \\
\text { distinguindo a afi- } \\
\text { nação e a função. }\end{array}$ & \\
\hline IV & $\begin{array}{l}\text { Escalas (syste- } \\
\text { mata) } \\
\text { Trata-se da } \\
\text { quarta parte da } \\
\text { Harmonia. }\end{array}$ & 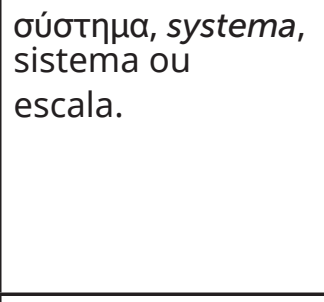 & 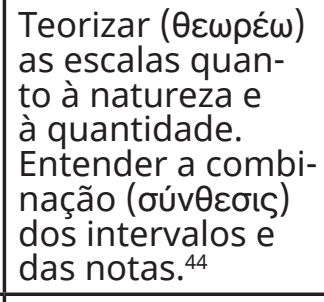 & $\begin{array}{l}\text { Nessa seção, o } \\
\text { músico necessita } \\
\text { do conhecimento } \\
\text { das partes ante- } \\
\text { riores, tais quais } \\
\text { notas e intervalos. }\end{array}$ \\
\hline v & $\begin{array}{l}\text { Tons (tonos) } \\
\text { A quinta parte } \\
\text { trata do posi- } \\
\text { cionamento das } \\
\text { notas. }\end{array}$ & $\begin{array}{l}\text { Tóvos, } \\
\text { tonus, } \\
\text { tom/tonalidade. }\end{array}$ & $\begin{array}{l}\text { Entender como } \\
\text { a nota é execu- } \\
\text { tada nas escalas } \\
\text { de modo a pro- } \\
\text { duzir melodia } \\
\left(\mu \varepsilon \lambda \omega \delta \varepsilon ́(\omega) .{ }^{45}\right.\end{array}$ & $\begin{array}{l}\text { Aqui o estudo já } \\
\text { ocorre em função } \\
\text { da melodia. }\end{array}$ \\
\hline
\end{tabular}

39 Entre parênteses, insere-se o correspondente latino empregado por Fulgêncio. Note-se que o autor latino altera a ordem, colocando em terceiro lugar o estudo das escalas (systemata), antes da seção sobre as notas (ptongos).

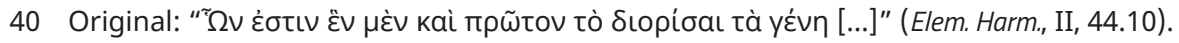

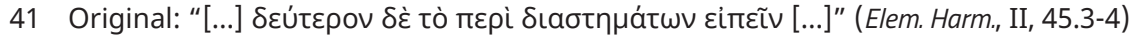

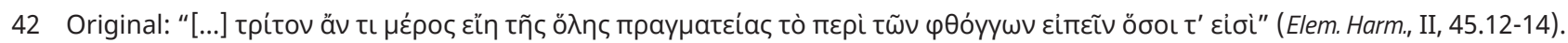

43 Termo não encontrado nos antigos romanos (senão pelos autores da Antiguidade tardia).

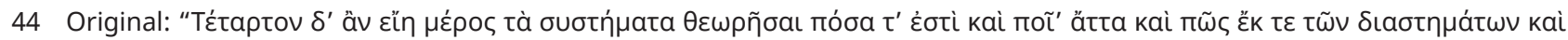

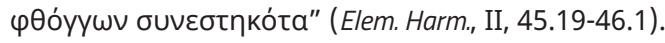

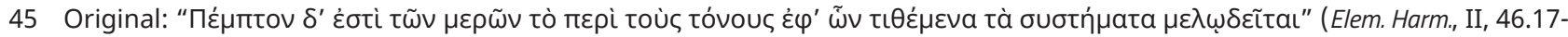
18). 


\begin{tabular}{|c|c|c|c|c|}
\hline & Partes & $\begin{array}{l}\text { Elementos primor- } \\
\text { diais }\end{array}$ & Objetivos & Observação \\
\hline I & $\begin{array}{l}\text { Gêneros (gene- } \\
\text { ra) } \\
\text { A primeira parte } \\
\text { do estudo de Har- } \\
\text { monia. }{ }^{30}\end{array}$ & $\begin{array}{l}\text { үévos, } \\
\text { genus, } \\
\text { gênero. }\end{array}$ & 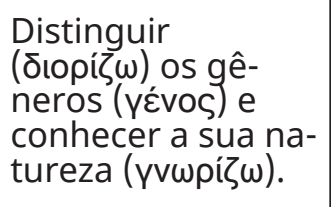 & \\
\hline II & $\begin{array}{l}\text { Intervalos (dias- } \\
\text { temata) } \\
\text { A segunda parte } \\
\text { propõe falar } \\
\text { (Ẽ̂inov) sobre os } \\
\text { intervalos. }{ }^{41}\end{array}$ & 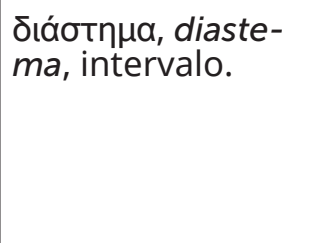 & $\begin{array}{l}\text { Conhecer a natu- } \\
\text { reza dos interva- } \\
\text { los, distinguindo- } \\
\text {-os da forma mais } \\
\text { completa possível. }\end{array}$ & \\
\hline III & $\begin{array}{l}\text { Notas musicais } \\
\text { (ptongos) } \\
\text { A terceira parte } \\
\text { trata das notas } \\
\text { do modo mais } \\
\text { completo possí- } \\
\text { vel. }{ }^{42}\end{array}$ & $\begin{array}{l}\varphi \theta \text { óyyos, pton- } \\
\text { gus } 43 \text { vox, nota. }\end{array}$ & $\begin{array}{l}\text { Conhecer a na- } \\
\text { tureza das notas, } \\
\text { distinguindo a afi- } \\
\text { nação e a função. }\end{array}$ & \\
\hline VI & $\begin{array}{l}\begin{array}{l}\text { Modulação (me- } \\
\text { tabolas) }\end{array} \\
\text { A sexta parte } \\
\text { discorre sobre } \\
\text { o fenômeno da } \\
\text { modulação. }\end{array}$ & 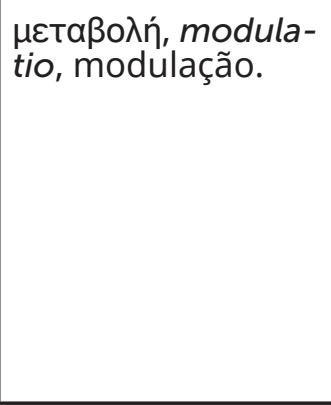 & $\begin{array}{l}\text { Compreender } \\
\text { a natureza da } \\
\text { modulação e } \\
\text { também como ela } \\
\text { acontece. Saber } \\
\text { quantas modula- } \\
\text { ções existem e em } \\
\text { quais intervalos. }\end{array}$ & $\begin{array}{l}\text { Há melodias sim- } \\
\text { ples que não pos- } \\
\text { suem modulação; } \\
\text { mas há aquelas } \\
\text { que possuem mo- } \\
\text { dulação. }{ }^{46} \text { Trata- } \\
\text {-se doo estudo de } \\
\text { modulação, ainda } \\
\text { em teor abstra- } \\
\text { to, em função da } \\
\text { melodia. }\end{array}$ \\
\hline VII & $\begin{array}{l}\text { Melodia (melo- } \\
\text { pias) } \\
\\
\text { A sétima e última } \\
\text { parte da Harmo- } \\
\text { nia trata da cons- } \\
\text { trução da melo- } \\
\text { dia ( } \mu \text { domolía), } \\
\text { isto é, dos princí- } \\
\text { pios que regem } \\
\text { a composição de } \\
\text { melodias. }\end{array}$ & $\begin{array}{l}\mu \varepsilon \dot{\lambda} \mathrm{os}_{\text {, }} \\
\text { melum/melos } \\
\text { melodia. }\end{array}$ & $\begin{array}{l}\text { Estudar a cons- } \\
\text { trução melódica } \\
\text { ( } \mu \varepsilon \lambda \text { onolía).47 }\end{array}$ & 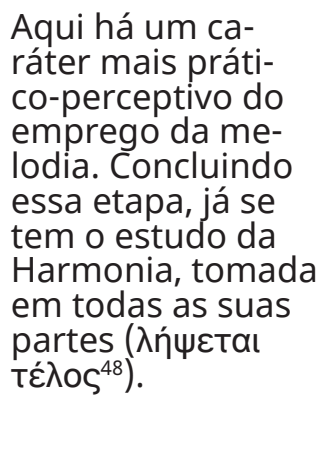 \\
\hline
\end{tabular}

Quadro 1: As partes do estudo de Harmonia, segundo Aristóxeno. Fonte: Elaboração própria.

A divisão do estudo de Harmonia tem seu fundamento em função da interdepen-

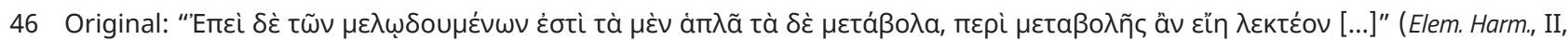
47.17-18).

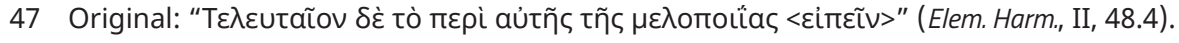

48 Elem. Harm., II, 48.10. 
dência das partes, haja vista os conceitos necessários à compreensão da etapa seguinte. Essa organização é esclarecedora porque planeja a gradação do conhecimento. Assim, a última etapa depende do conhecimento das seis anteriores; mas a segunda etapa, somente da primeira; já uma terceira parte prescinde de conceitos posteriores, em função dos elementos subsumidos. Há, em síntese, uma organização gradual, a partir de que se infere uma postura didática e metódica de Aristóxeno.

Além da divisão das partes do estudo de Harmonia, organizadas no Quadro 1, também se arrolam, em novo quadro, alguns conceitos que compõem, principalmente, a Harmonia. Esse segundo quadro apresenta 65 entradas que procuram dispor noções fundamentais, em caráter sintético, como um glossário, a fim de tentar apontar algum princípio lógico-teórico.

O quadro é composto por cinco colunas em que se dispõe uma numeração, em algarismo arábico, à guisa de contabilização de entradas, e mais quatro colunas relativas ao conteúdo lexical. Na segunda, indicam-se os termos; na terceira, o respectivo significado, em contexto musical. Após essas colunas, insere-se outra em que se aponta, se necessário, o termo solidário ao léxico da entrada, conforme a natureza da expressão. Por exemplo, ao verbete yévos (génos), associam-se as expressões diótovos

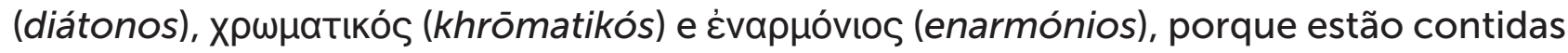
no primeiro; já ßapútns (barýtēs, grave) faz relação com ółútns (oxýtēs, agudo), porque se opõem. Essas relações lexicais podem ajudar a perceber a constituição metodológica da obra de Aristóxeno ou a sua sistemática. Por fim, há, ainda, a localização das expressões na obra do músico, priorizando a primeira ocorrência ou o trecho mais relevante.

A ausência, em alguns autores, de um rigor epistemológico ou de uma falta de sistematização teórica foi alvo de crítica por Aristóxeno. O seu julgamento de alguns teóricos anteriores consistia muito em função da falta de exame sistemático ou de demonstração. Por essa razão, procurando fazer o que criticou, estendeu o estudo dos sistemas ou das escalas a um alto nível de "sistematização". Afirma Gibson (2005, p. 162) que "Aristóxeno critica os teóricos anteriores pela falta de exame sistêmico e promete, no Livro I [dos Elementos de Harmonia], que fará uma discussão extensa sobre os systemata [...]". ${ }^{49}$ Infelizmente, supõe-se que a descrição minuciosa dos systemata tenha sido uma das partes perdidas de seu Elementos de Harmonia.

\footnotetext{
A partir deles [dos "Elementos de Harmonia" e das obras de Cleônides], podemos inferir que uma enumeração sistemática dos sistemas de escala foi uma das principais inovações das secções perdidas dos Elementos de Harmonia. É provável

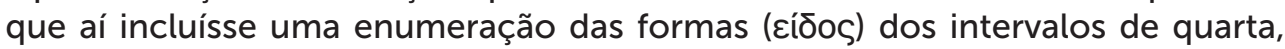
quinta e oitava e uma descrição dos sistemas perfeitos máximo e mínimo. (GIBSON, 2005, p. 162). ${ }^{50}$
}

\footnotetext{
49 Original: "Aristoxenus criticises earlier theorists for their lack of systematic examination and he promises in Book I that his own discussion of systemata will be exhaustive [...]".

50 Original: "From these, we can presume that a systematic enumeration of scale systems was one of the principal features of

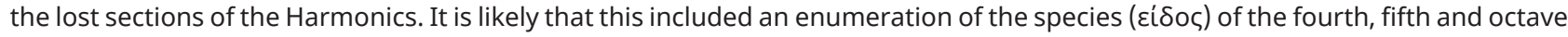
and a description of the greater and lesser perfect systems".
} 
Tendo em vista esse processo de "sistematização" teórica, principalmente sobre os systemata, o Quadro 2 procura evidenciar a coerência terminológica da teoria, mas sem pretensão de fôlego. Trata-se, na verdade, de uma amostragem, já que o quadro a seguir não tem índole exaustiva. Quanto às variantes, em função de metaplasmos, optou-se, em muitos casos, pelo nominativo singular; em outros, pela forma mais consagrada da palavra.

Conceito Conteúdo semântico Termo solidário Referência

\begin{tabular}{|c|c|c|c|c|}
\hline & Conceito & Conteúdo semântico & Termo solidário & Referência \\
\hline 1 & áywүń (agōgế) & $\begin{array}{l}\text { Continuidade geral da melo- } \\
\text { dia. }\end{array}$ & & $\begin{array}{l}\text { Elem. Harm. I, } \\
17.21 .\end{array}$ \\
\hline 2 & 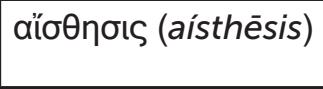 & Percepção auditiva. & & $\begin{array}{l}\text { Elem. Harm. I, } \\
17.12 .\end{array}$ \\
\hline 3 & ä̀oyos (álogos) & Irracional [rítmica], arrítmico. & ṕntós (rhētós) & $\begin{array}{l}\text { Elem. Harm. I, } \\
22.1 .\end{array}$ \\
\hline 4 & 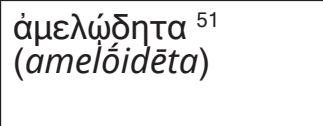 & $\begin{array}{l}\text { Amelódico, não melódico [em } \\
\text { função da divisibilidade de } \\
\text { intervalos]. }\end{array}$ & 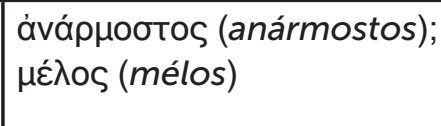 & $\begin{array}{l}\text { Elem. Harm. I, } \\
27.19 .\end{array}$ \\
\hline 5 & $\begin{array}{l}\text { ávápuootos (anár- } \\
\text { mostos) }\end{array}$ & $\begin{array}{l}\text { Melodia falsa [pela colocação } \\
\text { de intervalos simples]. }\end{array}$ & 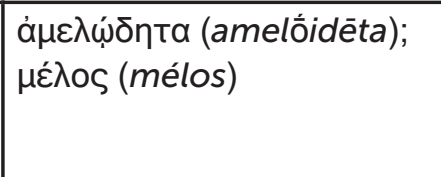 & $\begin{array}{l}\text { Elem. Harm. I, } \\
65.14 . \\
\text { Elem. Rit. II, } \\
\text { 19.4. }\end{array}$ \\
\hline 6 & 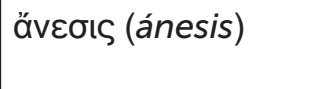 & $\begin{array}{l}\text { Distensão, relaxamento [de } \\
\text { cordas, da voz]. }\end{array}$ & غ̇пі́табıৎ (epítasis) & $\begin{array}{l}\text { Elem. Harm. I, } \\
8.2 \text {. }\end{array}$ \\
\hline 7 & 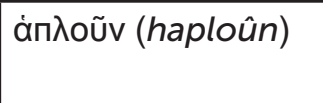 & $\begin{array}{l}\text { Simples [subclassificação de } \\
\text { escala]. }\end{array}$ & 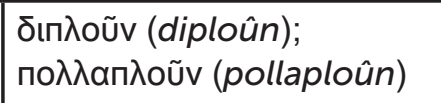 & $\begin{array}{l}\text { Elem. Harm, I, } \\
\text { 23.5. }\end{array}$ \\
\hline 8 & $\begin{array}{l}\text { d̀puovía (harmo- } \\
\text { nía) }\end{array}$ & $\begin{array}{l}\text { Estudo das escalas. Conheci- } \\
\text { mento da enarmonia [primeiro } \\
\text { gênero do qual os outros } \\
\text { derivam]. Escala ou sistema } \\
\text { cujas partes foram ajustadas } \\
\text { conforme suas próprias rela- } \\
\text { ções. A lei da Melodia. Junção } \\
\text { de elementos. Acordoamento. }\end{array}$ & & $\begin{array}{l}\text { Elem. Harm. I, } \\
6.8 . \\
\text { Elem. Rit. II, } \\
\text { 20.33. }\end{array}$ \\
\hline 9 & $\begin{array}{l}\text { áoú } \mu \varphi \omega v o s ~(a s y ́ m-~ \\
\text { phōnos) }\end{array}$ & Discordante. Não harmonioso. & бú $\mu \varphi \omega v o \varsigma$ (sýmphōnos) & $\begin{array}{l}\text { Elem. Harm. II, } \\
37.7 \text {. }\end{array}$ \\
\hline 10 & 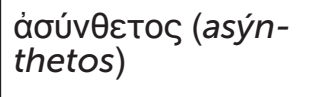 & $\begin{array}{l}\text { Simples, não composto } \\
\text { [a tons e escalas]. }\end{array}$ & 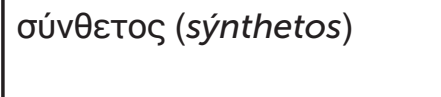 & $\begin{array}{l}\text { Elem. Harm. II, } \\
\text { 75.19. }\end{array}$ \\
\hline 11 & ßapútns (barýtēs) & $\begin{array}{l}\text { Gravidade [do som], profundi- } \\
\text { dade sonora. }\end{array}$ & ółútns (oxýtēs) & $\begin{array}{l}\text { Elem. Harm. I, } \\
8.2 \text {. }\end{array}$ \\
\hline
\end{tabular}

51 Exemplo de neologismo em Aristóxeno. Por exemplo, é amelódica a escala com divisibilidade de intervalos menor que meio, no caso da diatônica, ou um quarto, para a enarmônica. Desse modo, é amelódico porque não é possível configurar um sistema, isto é, não é passível de colocar-se em música (Elem. Harm. I, 33.4). 


\begin{tabular}{|c|c|c|c|c|}
\hline & Conceito & Conteúdo semântico & Termo solidário & Referência \\
\hline 12 & үर́vos (génos) & Gênero musical. & 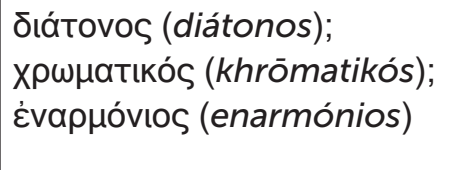 & $\begin{array}{l}\text { Elem. Harm. I, } \\
6.18 . \\
\text { Elem. Rit. II, } \\
20.20 \text {. }\end{array}$ \\
\hline 13 & 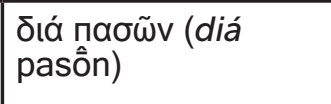 & Oitava. & 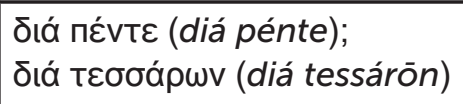 & $\begin{array}{l}\text { Elem. Harm. I, } \\
6.18 .\end{array}$ \\
\hline 14 & 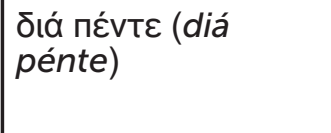 & O intervalo de quinta. & 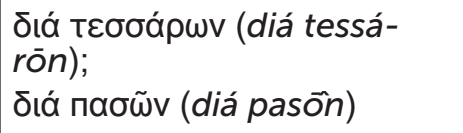 & $\begin{array}{l}\text { Elem. Harm. I, } \\
11.7 .\end{array}$ \\
\hline 15 & 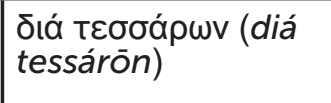 & O intervalo de quarta. & 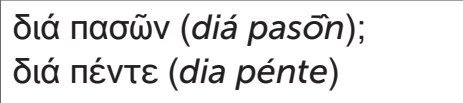 & $\begin{array}{l}\text { Elem. Harm. I, } \\
\text { 9.18. }\end{array}$ \\
\hline 16 & 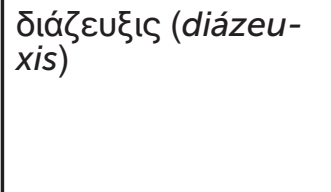 & $\begin{array}{l}\text { Escala disjunta. Disjuntos } \\
\text { [a tetracordes sucessivos; } \\
\text { quando, em dois tetracordes, a } \\
\text { primeira nota de um é a última } \\
\text { do outro]. }\end{array}$ & 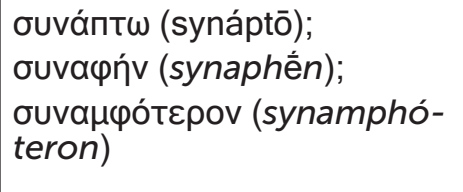 & $\begin{array}{l}\text { Elem. Harm. I, } \\
22.17 . \\
\text { Elem. Harm. II, } \\
73.4 \text {. }\end{array}$ \\
\hline 17 & 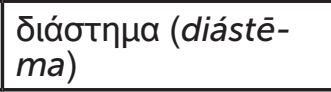 & Intervalo, distância. & & \begin{tabular}{|l} 
Elem. Harm. I, \\
8.8. \\
\end{tabular} \\
\hline 18 & 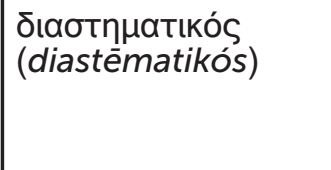 & $\begin{array}{l}\text { Espacial, que procede por } \\
\text { intervalos, não contínuo. }\end{array}$ & бuvexńc (synekhếs) & $\begin{array}{l}\text { Elem. Harm. I, } \\
8.8 . \\
\text { Elem. Rit. II, } \\
\text { 18.25. }\end{array}$ \\
\hline 19 & 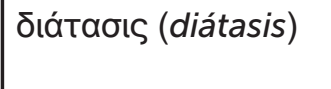 & Dilatação, tensionamento. & غ̇пítaбıৎ (epítasis) & $\begin{array}{l}\text { Elem. Harm. I, } \\
8.2 .\end{array}$ \\
\hline 20 & $\begin{array}{l}\text { diátovos (diáto- } \\
\text { nos) }\end{array}$ & Diatônico [gênero, escala]. & 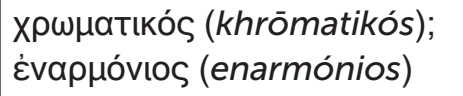 & $\begin{array}{l}\text { Elem. Harm. I, } \\
6.11 .\end{array}$ \\
\hline 21 & 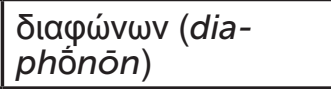 & $\begin{array}{l}\text { Soar discordante, soar distin- } \\
\text { to, emitir nota falsa. }\end{array}$ & 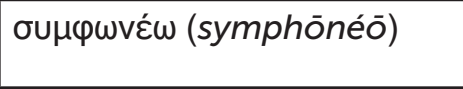 & $\begin{array}{l}\text { Elem. Harm. I, } \\
21.21 .\end{array}$ \\
\hline 22 & dícoıৎ (díesis) & $\begin{array}{l}\text { Menor intervalo em uma } \\
\text { escala. O semitom na escala } \\
\text { diatônica ou o quarto de tom } \\
\text { na enarmônica. }\end{array}$ & & $\begin{array}{l}\text { Elem. Harm. I, } \\
28.1 .\end{array}$ \\
\hline 23 & 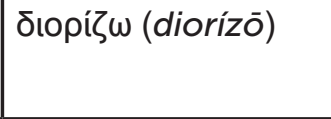 & $\begin{array}{l}\text { Ato de delimitar, diferenciar, } \\
\text { distinguir, estabelecer [a natu- } \\
\text { reza dos sons musicais]. }\end{array}$ & & $\begin{array}{l}\text { Elem. Harm. II, } \\
50.8 \text {. }\end{array}$ \\
\hline 24 & 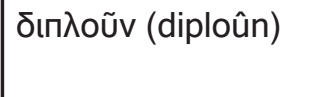 & $\begin{array}{l}\text { Dupla, repetida [subclassifica- } \\
\text { ção de escala]. }\end{array}$ & 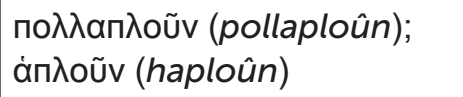 & $\begin{array}{l}\text { Elem. Harm. I, } \\
\text { 23.5. }\end{array}$ \\
\hline 25 & 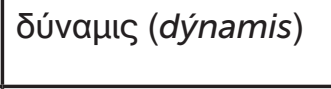 & $\begin{array}{l}\text { Função ou valor [de uma nota } \\
\text { na escala]. }\end{array}$ & 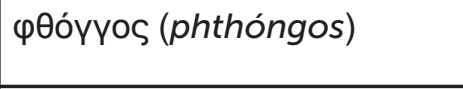 & $\begin{array}{l}\text { Elem. Harm. II, } \\
\text { 45.16. }\end{array}$ \\
\hline 26 & 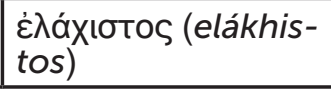 & $\begin{array}{l}\text { Mínimo, o menor [intervalo, } \\
\text { distância]. }\end{array}$ & 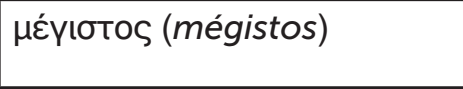 & $\begin{array}{l}\text { Elem. Harm. I, } \\
19.7 .\end{array}$ \\
\hline 27 & $\begin{array}{l}\text { Évaphóvios (enar- } \\
\text { mónios) }\end{array}$ & Enarmônico [gênero, escala]. & 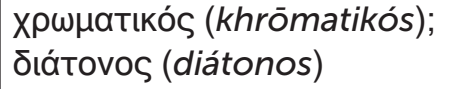 & $\begin{array}{l}\text { Elem. Harm. I, } \\
6.11 .\end{array}$ \\
\hline
\end{tabular}




\begin{tabular}{|c|c|c|c|c|}
\hline & Conceito & Conteúdo semântico & Termo solidário & Referência \\
\hline 28 & غ̇пítaбıৎ (epítasis) & $\begin{array}{l}\text { Tensão, retesamento [de } \\
\text { cordas]. }\end{array}$ & áveбıৎ (ánesis) & $\begin{array}{l}\text { Elem. Harm. I, } \\
8.2 .\end{array}$ \\
\hline 29 & 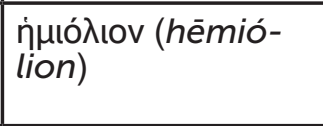 & $\begin{array}{l}\text { Croma especial [contém um } \\
\text { e meio]. Inteiro e metade do } \\
\text { inteiro. A razão } 3: 2 \text {. }\end{array}$ & 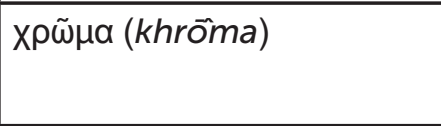 & $\begin{array}{l}\text { Elem. Harm. II, } \\
32.1 \text {. }\end{array}$ \\
\hline 30 & $\begin{array}{l}\text { ṅutтovíou (hēmito- } \\
\text { níou) }\end{array}$ & $\begin{array}{l}\text { Semitom. Uma das duas par- } \\
\text { tes que contém um tóvos. }\end{array}$ & Tóvos (tónos) & $\begin{array}{l}\text { Elem. Harm. II, } \\
31.15 \text {. }\end{array}$ \\
\hline 31 & kívnбıৎ (kínēsis) & Movimento [da fala ou da voz]. & & $\begin{array}{l}\text { Elem. Harm. I, } \\
14.5 .\end{array}$ \\
\hline 32 & 入ıxavós (likhanós) & $\begin{array}{l}\text { A corda tocada com o indica- } \\
\text { dor [na lira]. }\end{array}$ & & $\begin{array}{l}\text { Elem. Harm. I, } \\
29.1 .\end{array}$ \\
\hline 33 & $\begin{array}{l}\mu \varepsilon \dot{\gamma} \varepsilon \theta \text { os (mége- } \\
\text { thos) }\end{array}$ & $\begin{array}{l}\text { Extensão métrica, compasso, } \\
\text { intensidade sonora, extensão. }\end{array}$ & & $\begin{array}{l}\text { Elem. Harm. I, } \\
6.18 . \\
\text { Elem. Rit. II, } \\
20.27 \text {. }\end{array}$ \\
\hline 34 & 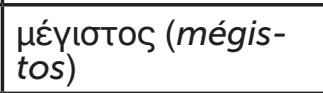 & $\begin{array}{l}\text { Máximo, o maior [para interva- } \\
\text { lo, distância]. }\end{array}$ & 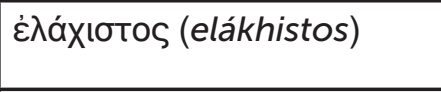 & $\begin{array}{l}\text { Elem. Harm. I, } \\
19.7 .\end{array}$ \\
\hline 35 & 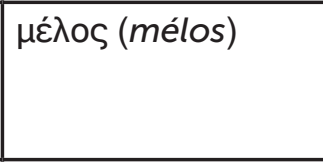 & $\begin{array}{l}\text { Música [em sistema], frase } \\
\text { musical [em contexto], canção, } \\
\text { melodia instrumental, melodia } \\
\text { monódica. }\end{array}$ & 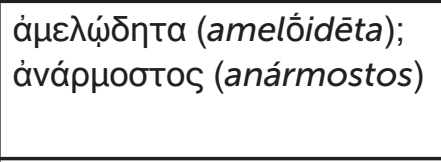 & $\begin{array}{l}\text { Elem. Harm. I, } \\
9.18 .\end{array}$ \\
\hline 36 & $\mu \varepsilon ́ \sigma \eta$ (mésē) & $\begin{array}{l}\text { A nota mais aguda do menor } \\
\text { tetracorde na oitava. }\end{array}$ & 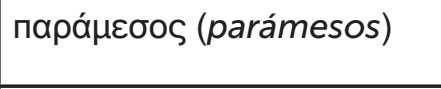 & $\begin{array}{l}\text { Elem. Harm. I, } \\
28.10 .\end{array}$ \\
\hline 37 & 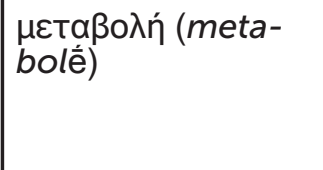 & $\begin{array}{l}\text { Modulação [de tom, de gênero } \\
\text { ou escala]. }\end{array}$ & & $\begin{array}{l}\text { Elem. Harm. II, } \\
43.14 \\
\text { Elem. Rit. II, } \\
20.21 \text {. }\end{array}$ \\
\hline 38 & 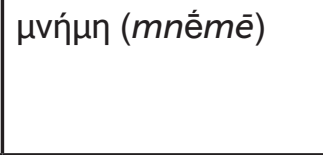 & $\begin{array}{l}\text { Memória musical do ouvinte. } \\
\text { Percepção musical. Relação } \\
\text { entre o som passado e o som } \\
\text { presente. }\end{array}$ & 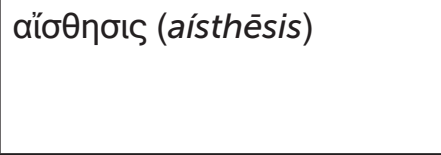 & $\begin{array}{l}\text { Elem. Harm. II, } \\
\text { 48.16. }\end{array}$ \\
\hline 39 & $\begin{array}{l}\text { ółútns (oxýtēs) } \\
\text { [ơßús (oxýs)]. }\end{array}$ & $\begin{array}{l}\text { Acuidade [do som], agudeza } \\
\text { sonora. }\end{array}$ & ßapútns (barýtēs) & $\begin{array}{l}\text { Elem. Harm. I, } \\
8.2 .\end{array}$ \\
\hline 40 & 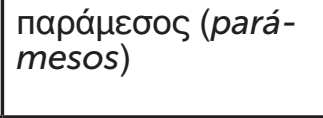 & $\begin{array}{l}\text { A nota mais grave em um } \\
\text { tetracorde disjunto. A corda } \\
\text { próxima depois da mese. }\end{array}$ & 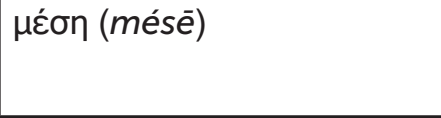 & $\begin{array}{l}\text { Elem. Harm. II, } \\
\text { 43.7. }\end{array}$ \\
\hline 41 & $\begin{array}{l}\text { пapunátn (parypá- } \\
\text { tē) }\end{array}$ & $\begin{array}{l}\text { A corda ou nota depois da } \\
\text { únótn (hypátē). }\end{array}$ & únótn (hypáte) & $\begin{array}{l}\text { Elem. Harm. I, } \\
\text { 29.1. }\end{array}$ \\
\hline 42 & 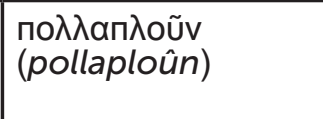 & $\begin{array}{l}\text { Múltipla, não simples e não } \\
\text { direta [subclassificação de } \\
\text { escala]. }\end{array}$ & 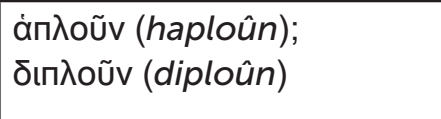 & $\begin{array}{l}\text { Elem. Harm. I, } \\
23.5 .\end{array}$ \\
\hline 43 & пukvós (pyknós) & $\begin{array}{l}\text { Pícno. Parte de um tetracorde } \\
\text { em que os intervalos peque- } \\
\text { nos estão concentrados. }\end{array}$ & & $\begin{array}{l}\text { Elem. Harm. I, } \\
12.10 . \\
\text { Elem. Rit. II, } \\
24.19 .\end{array}$ \\
\hline 44 & p̀ntós (rhētós) & Distinto, racional. & ä̀oyos (álogos) & $\begin{array}{l}\text { Elem. Harm. I, } \\
22.1 .\end{array}$ \\
\hline
\end{tabular}




\begin{tabular}{|c|c|c|c|c|}
\hline & Conceito & Conteúdo semântico & Termo solidário & Referência \\
\hline 45 & 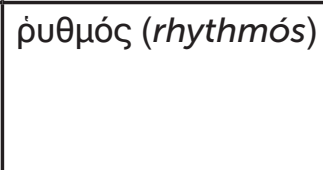 & $\begin{array}{l}\text { Tempo [musical]. Medida } \\
\text { temporal. Movimentação repe- } \\
\text { titiva. Regularidade. Número. } \\
\text { Contagem. }\end{array}$ & & $\begin{array}{l}\text { Elem. Harm. I, } \\
\text { 43.15. } \\
\text { Elem. Rit. I, } \\
2.2 .\end{array}$ \\
\hline 46 & otáoıı (stásis) & $\begin{array}{l}\text { Posicionamento [de notas], } \\
\text { colocação, afixação, deter- } \\
\text { minação [da voz, de notas], } \\
\text { distensão de corda. }\end{array}$ & Táoıৎ (tásis) & $\begin{array}{l}\text { Elem. Harm. I, } \\
17.4 .\end{array}$ \\
\hline 47 & 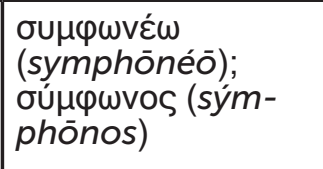 & $\begin{array}{l}\text { Soar concordante, soar em } \\
\text { conjunto, soar de modo unís- } \\
\text { sono ou único. Acompanhar } \\
\text { [um músico]. }\end{array}$ & 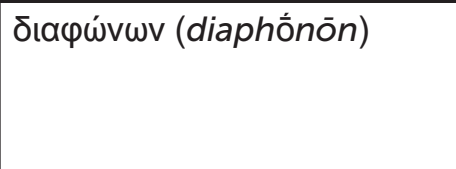 & $\begin{array}{l}\text { Elem. Harm. I, } \\
21.21 . \\
\text { Elem. Rit. II, } \\
23.5 .\end{array}$ \\
\hline 48 & $\begin{array}{l}\sigma u v \alpha \mu \varphi o ́ t \varepsilon p o v \\
\text { (synamphóteron) }\end{array}$ & Escala mista. & 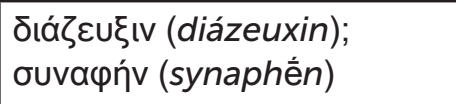 & $\begin{array}{l}\text { Elem. Harm. I, } \\
\text { 22.18. }\end{array}$ \\
\hline 49 & бuvó́ntw (synáptō) & $\begin{array}{l}\text { Estar conjunto [a tetracordes } \\
\text { sucessivos]. }\end{array}$ & 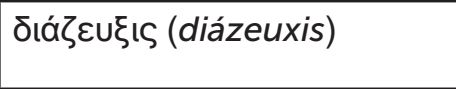 & $\begin{array}{l}\text { Elem. Harm. II, } \\
73.4 .\end{array}$ \\
\hline 50 & $\begin{array}{l}\text { бuvạńv (sy- } \\
\text { naphēn) }\end{array}$ & $\begin{array}{l}\text { Escala conjunta; conjunção de } \\
\text { dois tetracordes. }\end{array}$ & 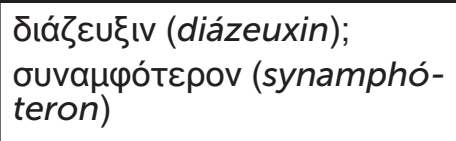 & $\begin{array}{l}\text { Elem. Harm. I, } \\
22.17 .\end{array}$ \\
\hline 51 & $\begin{array}{l}\text { бuvexńs } \\
\text { (synekhès) }\end{array}$ & $\begin{array}{l}\text { Contínuo [subcategoria de } \\
\text { escala]. }\end{array}$ & 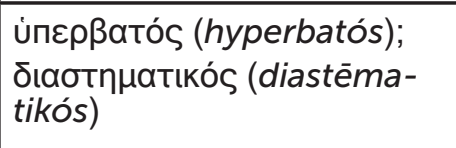 & $\begin{array}{l}\text { Elem. Harm. I, } \\
\text { 13.10. }\end{array}$ \\
\hline 52 & 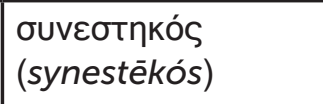 & $\begin{array}{l}\text { Em associação, combinado [a } \\
\text { escalas]. }\end{array}$ & 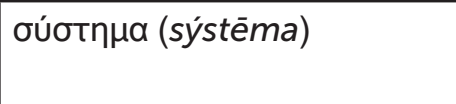 & $\begin{array}{l}\text { Elem. Harm. II, } \\
\text { 31.4. }\end{array}$ \\
\hline 53 & 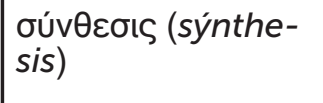 & $\begin{array}{l}\text { Combinação [de intervalos, de } \\
\text { notas], junção, composição. }\end{array}$ & 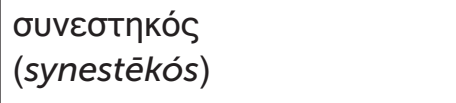 & $\begin{array}{l}\text { Elem. Harm. I, } \\
10.17 .\end{array}$ \\
\hline 54 & 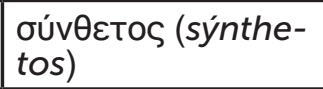 & $\begin{array}{l}\text { Composto, não simples, com- } \\
\text { plexo [a escalas e tons]. }\end{array}$ & 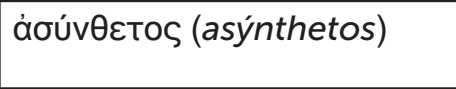 & $\begin{array}{l}\text { Elem. Rit. II, } \\
20.31 .\end{array}$ \\
\hline 55 & 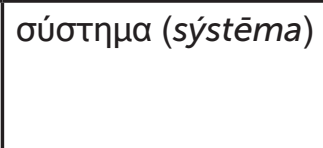 & $\begin{array}{l}\text { Sistema de intervalos, escala, } \\
\text { composição [de elementos]. }\end{array}$ & 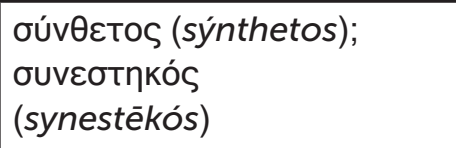 & $\begin{array}{l}\text { Elem. Harm. I, } \\
5.9 .\end{array}$ \\
\hline 56 & 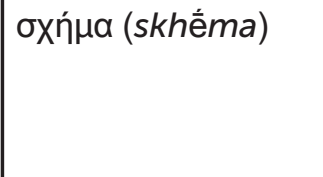 & $\begin{array}{l}\text { Figura, forma ou disposição } \\
\text { das partes. }\end{array}$ & & $\begin{array}{l}\text { Elem. Harm. I, } \\
11.4 . \\
\text { Elem. Rit. I, } \\
3.5 .\end{array}$ \\
\hline 57 & Tóoıৎ (tásis) & $\begin{array}{l}\text { Extensão [da voz], tensiona- } \\
\text { mento da corda. }\end{array}$ & otáoııৎ (stásis) & $\begin{array}{l}\text { Elem. Harm. I, } \\
\text { 8.2. }\end{array}$ \\
\hline 58 & 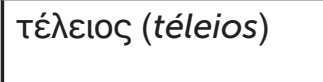 & $\begin{array}{l}\text { Máximo, completo, íntegro } \\
\text { [principalmente, a escalas]. }\end{array}$ & 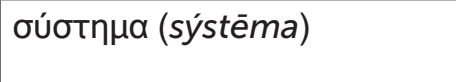 & $\begin{array}{l}\text { Elem. Harm. I, } \\
\text { 10.13. }\end{array}$ \\
\hline
\end{tabular}




\begin{tabular}{|c|c|c|c|c|}
\hline & Conceito & Conteúdo semântico & Termo solidário & Referência \\
\hline 59 & Tóvos (tónos) & $\begin{array}{l}\text { Afinação, elevação da voz, } \\
\text { tensão da voz, contração [do } \\
\text { músculo, da corda], nota musi- } \\
\text { cal. "Excesso de Quinta sobre } \\
\text { a Quarta". }{ }^{52}\end{array}$ & $\varphi \theta o ́ y y o s ~(p h t h o ́ n g o s)$ & $\begin{array}{l}\text { Elem. Harm. I, } \\
27.15 \\
\text { Elem. Rit. II, } \\
20.20 \text {. }\end{array}$ \\
\hline 60 & únótn (hypátē) & $\begin{array}{l}\text { A nota mais aguda do tetracor- } \\
\text { de mais alto. }\end{array}$ & парuпátᄁ (parypátē) & $\begin{array}{l}\text { Elem. Harm. I, } \\
29.1 .\end{array}$ \\
\hline 61 & $\begin{array}{l}\text { U̇nepßatós (hyper- } \\
\text { batós) }\end{array}$ & $\begin{array}{l}\text { Transposto, transiliente [cate- } \\
\text { goria de escala]. }\end{array}$ & бuvexńs (synekhếs) & $\begin{array}{l}\text { Elem. Harm. I, } \\
\text { 23.3. }\end{array}$ \\
\hline 62 & $\begin{array}{l}\text { بӨóyyos (phthón- } \\
\text { gos) }\end{array}$ & $\begin{array}{l}\text { Voz. Nota musical. Corda. } \\
\text { Som distinto. }\end{array}$ & Tóvos (tónos) & $\begin{array}{l}\text { Elem. Harm. I, } \\
20.17 .\end{array}$ \\
\hline 63 & 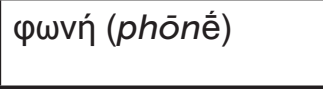 & $\begin{array}{l}\text { Fala. Voz humana. Som do } \\
\text { instrumento. }\end{array}$ & & $\begin{array}{l}\text { Elem. Harm. I, } \\
13.12 .\end{array}$ \\
\hline 64 & 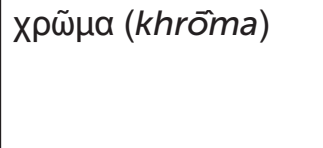 & $\begin{array}{l}\text { Modificação. Complexificação. } \\
\text { Escala cromática. }\end{array}$ & 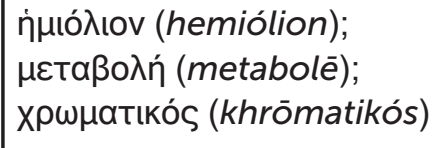 & $\begin{array}{l}\text { Elem. Harm. II, } \\
32.1 .\end{array}$ \\
\hline 65 & $\begin{array}{l}\text { xpwuatikós } \\
\text { (khrōmatikós) }\end{array}$ & Cromático [gênero, escala]. & 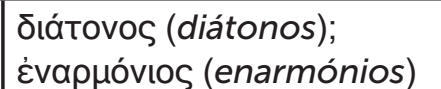 & $\begin{array}{l}\text { Elem. Harm. I, } \\
6.11 .\end{array}$ \\
\hline
\end{tabular}

Quadro 2: Alguns conceitos fundamentais em Aristóxeno. Fonte: Elaboração própria.

Em resumo, haja vista o processo de construção de uma teoria, Aristóxeno preocupa-se em definir a sua área de reflexão, a episteme musical e as tarefas que devem ser realizadas para compreender determinado domínio, quer a Harmonia quer o Ritmo, delimitando os conceitos ao sistema musical. Em outras palavras, limita a episteme à área musical, ainda mais em se tratando de noções que operam de modo muito semelhante entre as artes.

\section{EXPANSÃO DOS CONCEITOS GREGOS NA IDADE MÉDIA E NO RE- NASCIMENTO}

O Modo que serviu de base prás especulações teoricas dos gregos foi o Dorico ou Doristi considerado nacional por excelencia. Pela união de mais 2 Tetracordes a êle, um no agudo outro no grave, e repetição no grave da nota mais aguda, obtiveram a serie completa dos 15 sons diatonicos da Citara. A êste Sistema de 15 sons, acrescido dum Si Bemol central de função modulante, chamaram de Sistema Teleion (Sistema Completo) e consideraram imutável. (ANDRADE, 1929, p. 23).

Esta seção procura descrever o fenômeno de preservação ou alteração do conteúdo semântico de conceitos da literatura musical, a partir de Aristóxeno, considerando a

52 Elem. Harm., II, 57.1. 
forte influência entre o músico grego e os teóricos da Idade Média e do Renascimento, principalmente. Toma-se como modelo o conceito primordial de sistema, sob acepção

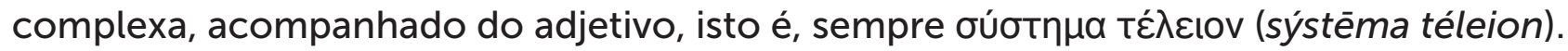

Embora бúotnua seja um léxico comum da língua grega (como termo isolado), atri-

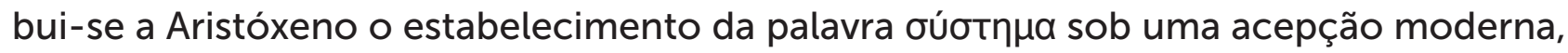

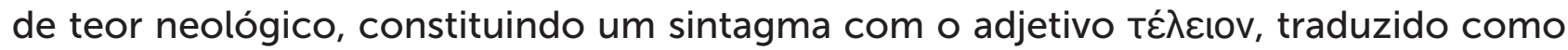
sistema máximo ou conjunto completo das notas musicais, principalmente. Note-se que, fora desta expressão musical ou mesmo da música, a palavra não se configurou como conceito filosófico nem científico na Antiguidade. Durante a Idade Média e no

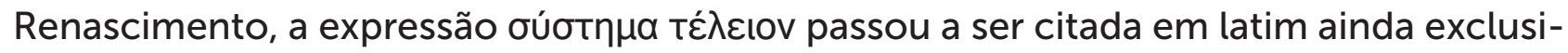
vamente no campo da teoria musical: absoluta, integra, et perfecta systemata. Henricus Glareanus (1547) foi, talvez, o primeiro a utilizar sua tradução literal: systema maximo. Já Vincenzo Galilei (1581) ${ }^{53}$ trabalha, em italiano, com a expressão systema massimo.

Mais tarde, Galileu Galilei (1632) adota sistema massimo, em italiano, para referir-se às cosmografias de Ptolomeu e Copérnico, valendo-se daquela mesma expressão dos estudos musicais de seu pai, Vincenzo, também seu professor, de quem recebeu forte influência intelectual, tendo com ele aprendido grego e latim. Galileu, tal como Kepler, apreciava metáforas musicais em sua filosofia e ciência - mesmo com a ressalva de que, ao contrário de Kepler, Galileu não levava a sério o mito lendário da Harmonia das Esferas. De qualquer modo, após Kepler e Galileu, a acepção de systema nas diver-

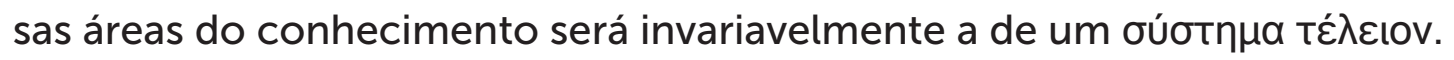

Já na literatura musical da Idade Média e do Renascimento, em específico - isto é, permanecendo em contexto teórico exclusivamente musical -, não se observaram outros usos do termo senão aquelas acepções assim estabelecidas:

a) restritas à semântica de escala musical;

b) restritas a subclassificações (systema immobile, systema maximum, systema integrum etc.);

c) junção de elementos em função (logo, sistemas na harmonia, no ritmo etc.);

d) potência de junção, no caso, de elementos constituintes, delimitada seja por esquemas, seja por elementos harmônicos, tais quais notas, intervalos, tons, que expressam funções específicas (logo, havendo a possibilidade, também, de assistemático, arrítmico, amelódico ${ }^{54}$ etc.).

Embora durante parte da Idade Média o conceito de systema tenha deixado de ser utilizado, esquecido e substituído no contexto da escolástica por expressões latinas como "doutrina", "instituição" ou "arte" (no sentido de "modo" ou "maneira"), ainda houve consideráveis teóricos que se mantiveram próximos das fontes gregas, sob expressão máxima em Aristóxeno. Remigius Altisiodorensis, por exemplo, afirmava que

[...] tom é a extensão no sistema grego; já no latino, o intervalo entre uma corda e outra com uma extensão predeterminada. (Musica, 931, 3-4) ${ }^{55}$

53 Pai de Galileu Galilei.

54 Conferir Quadro 2.

55 Original: "[...] verum tonus est spatium Graece systema Latine spatium inter chordam et chordam cum legitima quantitate". 
Note-se a acepção em um sentido que poderíamos entender como sistema harmônico, ou seja, a escala musical como relação entre as notas. Dessa forma, entendem-se as notas como alturas musicais e o tom como sinônimo de voz ou corda, no contexto latino, tal qual no português brasileiro dos tempos coloniais.

Ainda em relação às notas, destaquem-se as suas conjunções, tendo como referência os intervalos musicais, sua tessitura e demais possibilidades de representações numéricas. Assim, em outras palavras, Remi d'Auxerres, seu nome gentílico, no contexto da Musica enchiriadis (século IX), foi quem fortemente empregou o conceito grego de systema em grafia latina, dando-lhe um sentido substancial e consubstancial à expressão grega. Remi d'Auxerres afirma ainda que

[...] o sistema é a amplitude da voz, ou seja, um intervalo grande, como consequência dos vários modos, isto é, do som. (Musica, 931, 3-4, grifo nosso). ${ }^{56}$

Essa acepção é consoante a outros teóricos, inclusive a Hucbaldus. Em textos de Hucbald de Saint-Amand, contemporâneo e colega de Remi d'Auxerres (lembrando aqui também os três intervalos fundamentais referidos desde Filolau):

Assim também o diapasão (oitava), como é entendido por todos, produz consonância de oitava em oitava e contém em seu sistema duas superiores (isto é, a quarta e a quinta). Em relação a isso, a oitava é referida por todos como sinfonia, pois os antigos não usavam mais que oito cordas. (Musica, X, 8). ${ }^{57}$

Mantém-se, nessa afirmação, a operação de intervalos mediada sempre pelos referenciais da 4aㅡ, da $5^{\underline{a}}$ e da $8^{\underline{a}}$, respectivamente, diatessaron, diapente e diapason, em equivalência direta grega.

56 Original: "[...] systema est magnitudo vocis, id est magnum intervallum, ex multis modis, id est sonis".

57 Original: "Sic et Diapason, quod ex omnibus interpretatur, octavi ad octavum fit consonantia, duas (id est diatessaron et diapente) superiores in suo systemate continens. Quae symphonia ideo ex omnibus dicitur, quod antiqui non plus quam octo chordis utebantur". 
Aa,geminarū, fyftema, natura cum primo, quod hypodorì eft, prorfus ie dem,adiecit,conftituitóp octauum illodum, ab $\mathrm{H}_{y}$ podorio nihildifferen tem,eum autem $H_{y}$ permixoly dium uocauit,atq; totum fy ftema difdiapa fon hoc pacto completü eft. Sua uero cuiufuis Modi proslambanomene eftinfima chorda, fua item nete, fuprema, de mefe duplici ftatim furnus dis cturi. Bini item Modi diapente habent communem. Eft autem hic ordo abfoffynemmenon terachordo fimplex ac uniformis. Nequulla omnino eftcantilena qux non in aliquam iftorum Modorum formulã cadat. Can rilenx enim quę hodiefynemmenon tetrachordon cum mefis iungunt, $0 *$ limin tertia diapafon f pecie à $\mathrm{C}$, ade, inftiruebanț, utpriorelibro diximus. Sed huius rei hecc firdeferiptio.

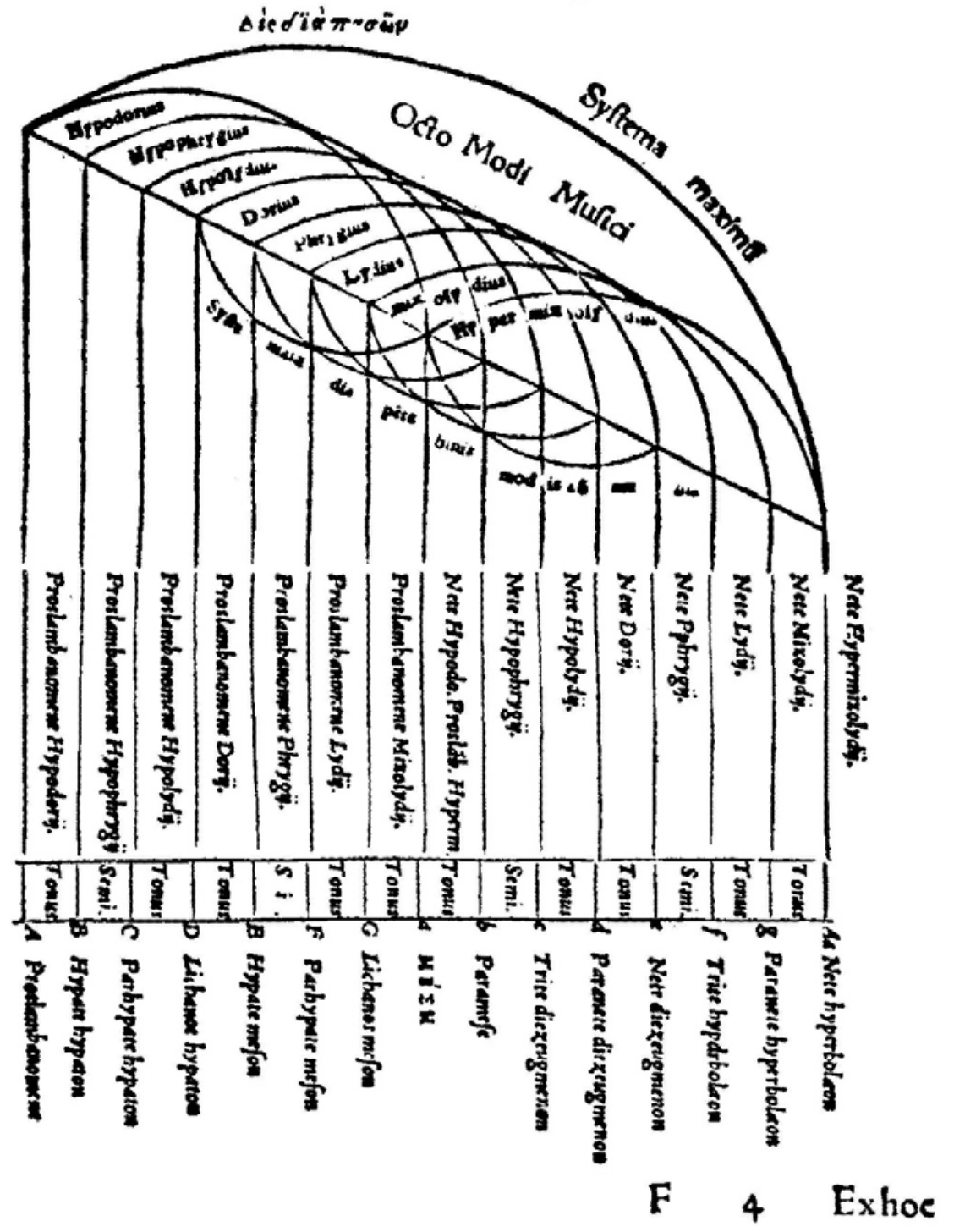


Posteriormente, vários autores medievais e do Renascimento vão retomar as concepções de Remi d'Auxerres, citando-o diretamente em relação às práticas musicais a partir do conceito de systema. Em menção: Rudolf von St. Trond (1070-1138), Heinrich Eger von Kalkar (1328-1408), Johannes Ciconia (1335-1411), Franchino Gaffuri (14511522), Georg Rhau (1488-1548), Sebald Heyden (1499-1561), Francisco Salinas (15131590), Girolamo Mei (1519-1594), Friedrich Beurhusius (metade do século XVI), Sethus Calvisius (1556-1615), entre outros, com destaque a Glareano (1488-1563).

Dessa forma, é possível arrolar os autores que, de forma mais direta, expressaram o conceito de systema a partir de Aristóxeno. No quadro a seguir, indicam-se os nomes desses estudiosos, seguidos do século de referência (aproximado), do título da obra (somente as primeiras palavras) e da quantidade de entradas localizadas (sem intenção exaustiva). Ainda, segue uma última coluna contendo observações genéricas, quer se trate mais de menção ao termo quer se trate de definição de conceito, à guisa de constatação. Ressalte-se que a varredura foi feita por meio do repositório de textos latinos intitulado Thesaurus Musicarum Latinarum, sitiado em ambiente virtual pela Indiana University Jacobs School of Music.

\begin{tabular}{|c|c|c|c|c|}
\hline Nome & Século & Início do título da obra & $\begin{array}{l}\text { Entradas } \\
\text { (systema) }\end{array}$ & Observações \\
\hline Adamus de Fulda & $x V$ & Musica... & 1 & Menção \\
\hline Anônimos* & IX-XI & $\begin{array}{l}\text { Scholia... / } \\
\text { Musica... }\end{array}$ & $\begin{array}{l}2 / \\
1\end{array}$ & Definição \\
\hline Bartolomé de Quevedo & $X V I$ & De vita et... & 2 & Menção \\
\hline Berno Augiensis & IX & Musica... & 1 & Menção \\
\hline Musica... & VI & De Institutione... & 1 & Definição \\
\hline Christiaan Huygens & XVII & Novus cyclus... & 3 & Comentário \\
\hline Eger von Kalkar & XIV & Cantuagium... & 1 & Definição \\
\hline Eucharius Hofman & XVI & Doctrina... & 1 & Menção \\
\hline Franchinus Gaffurius & XVI & $\begin{array}{l}\text { De harmonia... (I, II, III } \\
\text { e IV) / } \\
\text { Theorica... (II) }\end{array}$ & $\begin{array}{l}20 \text { (I), } 10 \\
\text { (II), } \\
3 \text { (III) e } 3 \\
\text { (IV) } \\
1\end{array}$ & $\begin{array}{l}\text { Definição, } \\
\text { explicação e } \\
\text { referenciação } \\
\text { (Ptolomeus) }\end{array}$ \\
\hline Franciscus Blanchinus & XVIII (post.) & De Tribus... & 4 & $\begin{array}{l}\text { Organologia, } \\
\text { (fonte mais } \\
\text { tardia) }\end{array}$ \\
\hline
\end{tabular}




\begin{tabular}{|c|c|c|c|c|}
\hline Nome & Século & Início do título da obra & $\begin{array}{l}\text { Entradas } \\
\text { (systema) }\end{array}$ & Observações \\
\hline Franciscus Salinas & XVI & De musica (III, IV e VII) & \begin{tabular}{|l|}
1 (III) \\
17 (IV) \\
1 (VII)
\end{tabular} & $\begin{array}{l}\text { Explicação, } \\
\text { referenciação } \\
\text { (Ptolomeus) }\end{array}$ \\
\hline Fredericus Beurhusius & $X V I$ & $\begin{array}{l}\text { Erotematum musicae... } \\
\text { (I e II) / } \\
\text { Musica Rudimenta... }\end{array}$ & $\begin{array}{l}32 \text { (I) e } 7 \\
\text { (II) / } \\
1 \text { (Musica) }\end{array}$ & Definição \\
\hline Georg Rhau & XVI & Enchiridion... & 2 & $\begin{array}{l}\text { Definição, } \\
\text { explicação, } \\
\text { referenciação } \\
\text { (Aristoxenus) }\end{array}$ \\
\hline Girolamo Mei & $X V I$ & De modis... & 20 & $\begin{array}{l}\text { Definição, } \\
\text { explicação, } \\
\text { referenciação } \\
\text { (Aristoxenus) }\end{array}$ \\
\hline Gobelinus Person & $X V$ & Tractatus musicae... & 3 & Explicação \\
\hline Henricus Glareanus & $X V I$ & $\begin{array}{l}\text { Dodecachordum (I, II } \\
\text { e III) }\end{array}$ & $\begin{array}{l}23 \text { (I), } 25 \\
\text { (II) } 12 \text { (III) }\end{array}$ & $\begin{array}{l}\text { Definição e } \\
\text { Explicação }\end{array}$ \\
\hline Hermann Finck & XVI & Practica musica... & 3 & $\begin{array}{l}\text { Definição e } \\
\text { Explicação }\end{array}$ \\
\hline Hieronymus Cardanus & XVI & De musica... & 2 & $\begin{array}{l}\text { Menção, } \\
\text { definição } \\
\text { (oitava) }\end{array}$ \\
\hline Ieronimus de Moravia & XIII & Tractatus... & 2 & Comentário \\
\hline Iohannes Cochlaeus & XVI & $\begin{array}{l}\text { Tetrachordum musi- } \\
\text { ces... }\end{array}$ & 6 & Definição \\
\hline Jacobus Leodiensis & XIV & Speculum... (VI) & 2 & Definição \\
\hline Joachim Burmeister & XVII & Musica Poetica... & 24 & $\begin{array}{l}\text { Definição, } \\
\text { complemen- } \\
\text { tação }\end{array}$ \\
\hline Joachimus Wolterstorpius & XVI & De musica... & 1 & \\
\hline Johannes Affligemensis & IX & De musica... & 2 & Definição \\
\hline Johannes Lippius & XVII & Synopsis... & 1 & Menção \\
\hline Johannes Valendrinus & XIV & Opusculum... & 1 & Definição \\
\hline Johannes Vogelsang & XVI & Musicae... & 2 & Definição \\
\hline Ladislaus de Zalka & $x V$ & Musica... & 2 & Menção \\
\hline Liban Jerzy & XVI & De musicae... & 1 & $\begin{array}{l}\text { Definição } \\
\text { (Sistema má- } \\
\text { ximo) }\end{array}$ \\
\hline
\end{tabular}




\begin{tabular}{|l|l|l|l|l|}
\hline Nome & Século & Início do título da obra & $\begin{array}{l}\text { Entradas } \\
\text { (systema) }\end{array}$ & Observações \\
\hline Martianus Capella & $\mathrm{V}$ & $\begin{array}{l}\text { De nuptiis... De harmo- } \\
\text { nia (I)/ } \\
\text { De nuptiis... De musica } \\
\text { (II) }\end{array}$ & $\begin{array}{l}5 \text { (I) / } \\
5 \text { (II) }\end{array}$ & $\begin{array}{l}\text { Definição, } \\
\text { explicação } \\
\text { (Fonte mais } \\
\text { antiga) }\end{array}$ \\
\hline Martinus Agricola & XVI & Rudimenta... & 1 & Definição \\
\hline Ottmar Luscinius & XVI & Musurgia seu... & 8 & $\begin{array}{l}\text { Definição, } \\
\text { referenciação } \\
\text { (Plutarchus) }\end{array}$ \\
\hline Remigius Altisiodorensis & IX (?) & Musica... & 20 & Definição \\
\hline Sebaldus Heyden & XVI & De arte canendi... & 3 & Menção \\
\hline Sethus Calvisius & XVI & Exercitaciones... & 4 & Comentário \\
\hline Stefan Monetarius & XVI & Epitoma utriusque... & 6 & Comentário \\
\hline
\end{tabular}

Quadro 3: Levantamento de autores a partir do Thesaurus Musicarum Latinarum. Fonte: Elaboração própria.

Desde Aristóxeno de Tarento e seus epígonos - a citar, Aristides Quintiliano, Cleônides e Ptolomeu, quem mais se valeu da expressão sýstema téleion -, o termo nunca se reduziu, filosoficamente, a um sistema exclusivo de notas e escalas musicais, mas manteve o vigor metafórico inicial, inferindo-se a presença, explícita ou implícita, de seu termo complementar, téleion, sob coerência de sentido que atribui a uma potencialidade máxima, passível de sistematicidade.

Nesse ponto, não seriam as notas, como parte dos elementos fundamentais da constituição harmônica, as únicas possibilidades de junção a configurar um sistema. Em outras palavras, não é exclusivamente a junção de notas o mecanismo responsável por produzir melodia, mas os diversos elementos combinantes, considerando, por exemplo,

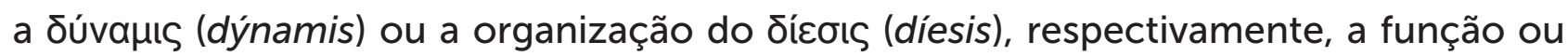
funcionalidade da nota e a possibilidade de divisão do tóvos (tónos). Além dos elementos da harmonia, também o p̉uӨjós (rhythmós) submete-se ao fenômeno do systema (análogo à harmonia), valendo-se de estruturas igualmente funcionáveis, passíveis de junções, em possibilidades mínimas e máximas. No caso do systema maximo (conferir Fig. 1), sua natureza é a continência exaustiva de elementos em que se insere o pros-

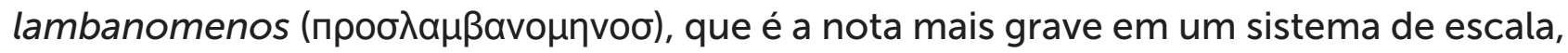
abaixo ao tetracorde inferior, mesmo em se tratando de uma não realização acústica.

A seguir, com a intenção de concluir esta seção, segue uma ilustração metafórica de nossa exposição teórico-musical, a partir de uma pintura atribuída ao flamengo Jan Van Eyck (1390-1441). Sem relação direta, apenas sugere-se, um pouco mais poeticamente e sem pretensão analítica, um diálogo entre pintura e música. 

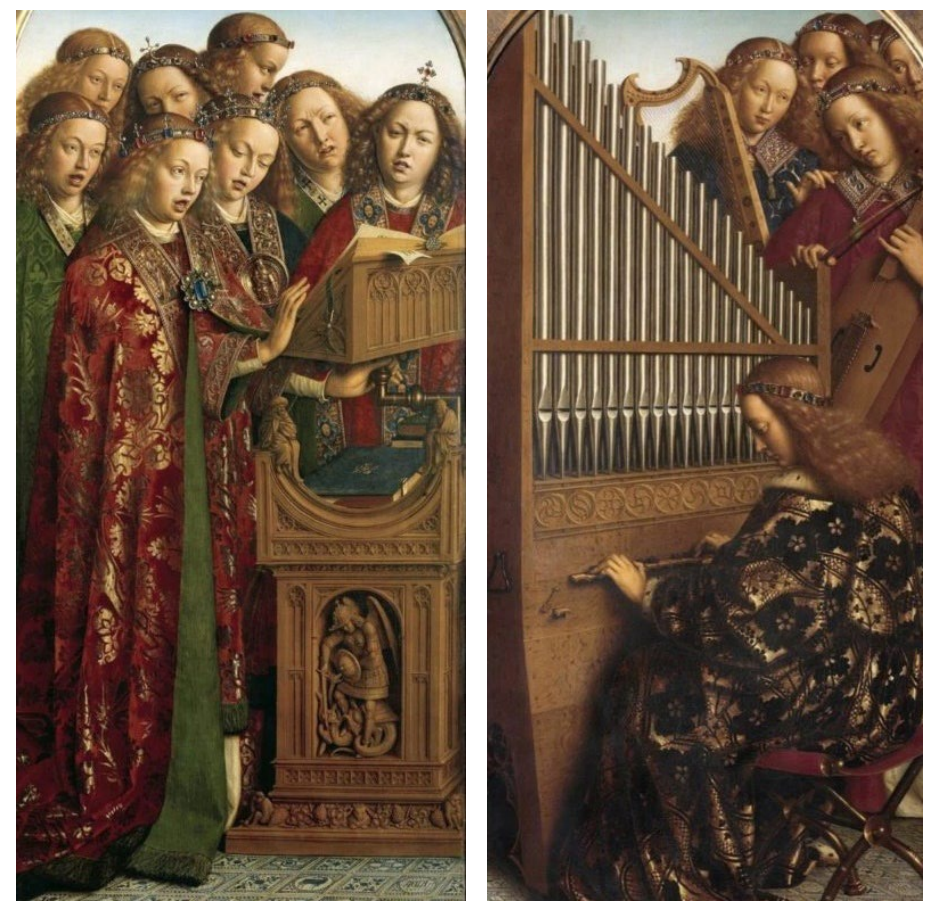

Fig. 2: Detalhe de dois painéis do Retábulo de Gante(1432), de Hubert e Jan Van Eyck. Fonte: Site da Catedral de São Bavão, em Gante, na Bélgica.

\section{CONSIDERAÇÕES FINAIS}

Há desdobramentos teórico-musicais que vieram de uma percepção metafórica e inventiva (de cunho neológico e poiético) sobre o mundo, por exemplo, a relação entre notas musicais e planetas, sob perspectiva imagética. Esse viés inicialmente místico ganhou outros olhares que configuraram os sons e o céu especialmente a partir de números (por exemplo, com Pitágoras), percebendo, em tudo, razões. Com Aristóxeno, pela primeira vez, houve a consolidação de uma teoria musical de fato, embora houvesse tentativas anteriores, desde Laso de Hermíone. Assim, partindo dos estudos de Pitágoras, não deixando de avaliar nenhum antecessor e mantendo diálogo com os seus contemporâneos atenienses, o discípulo de Aristóteles fundamentou sua teoria harmônica e rítmica, em que estabeleceu neologismos musicais (por assim dizer, uma teoria neológica no sentido de atribuir a um léxico comum da língua grega uma acepção moderna, de teor filosófico, inventiva e complexa).

Outrossim, já não apenas sob orientação filológica, percebe-se um fenômeno epistemológico de transmissão de noções primordiais que nascem da música e, perpassando mais de vinte séculos, chegam às ciências, sob o olhar de astrônomos, tais quais Galileu, Kepler e Newton, em continuidade. Nesse movimento, os teóricos de música medievos e renascentistas foram fundamentais para a continuidade de conceitos de teoria musical, sob invenção grega, mas perpetuação latina. 
Também, procurou-se compreender o modus faciendi de Aristóxeno, haja vista a construção teórica e seus desdobramentos nocionais. Vale incluir que, apesar de Cícero

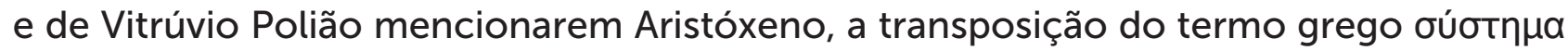
para systema, em latim, foi posterior, já a partir dos séculos IV ou V d.C., fruto dos trabalhos dos mitógrafos da Antiguidade tardia, leitores fundamentais de Aristóxeno, como Marciano Capela e Fábio Fulgêncio.

Chamou-se atenção do fenômeno epistemológico de transposição conceitual entre áreas, no caso, da música às ciências, e o seu apagamento filosófico posterior, já na acepção geral mais recente, pós-século XVIII, desfeito o sintagma, sýstēma téleion. Assim, em pesquisas futuras, talvez seja possível esclarecer relações de sentido entre a música e as outras áreas, principalmente as ditas "ciências duras".

Em outras palavras, dessas transposições epistemológicas mais recentes, parece haver o fortalecimento de um espírito antimetafórico, cada vez mais crescente nas ciências, que tenha desbotado o efeito lúdico primevo, que desejava ver nas notas musicais alguma semelhança com planetas e estrelas, num amálgama (coerente) do conhecimento.

Em palavras livres, não se trata de saber se o céu deixou de ser uma partitura infinita, mas de entender a perda do complemento téleion e do descrédito da área das Artes e da Filosofia quiçá por um positivismo descontrolado cujas consequências resultam no esquecimento da Música como campo do conhecimento. Ainda pior, surge, em tempos mais recentes, uma postura que não vê - ou porque não sabe ou porque não quer - a absoluta diferença entre a Música, sempre em sua solidariedade "poiética-prática-teórica", e a Kulturindustrie (Indústria da Cultura), cuja produção kitsch ${ }^{58}$ já está totalmente desvinculada da noínoıs (poíēsis).

Por fim, em alusão aos hexâmetros 84 a 86 do Livro I das Metamorfoses de Ovídio, poeta da Roma antiga, pergunta-se: quando voltaremos a olhar, de fato, o céu?
E, enquanto os outros seres estão voltados para o chão, [o artista de tudo ${ }^{59}$ ] deu ao homem um rosto sublime e ordenou olhar o céu e erguer, aos astros, o nobre semblante. ${ }^{60}$

Nessa passagem referente ao episódio da Antropogonia, a criação do homem, emblematicamente o poeta diferencia o homo dos outros animais pela capacidade de contemplação da natureza, ao mover a cabeça para o alto e olhar o céu. Esse ato é uma forma de respeito à púđıc (phýsis) da natureza (Ovídio era um epicurista), em contemplação theorica. O céu, as estrelas e os planetas, desse modo, guardariam - espécie de

58 A palavra alemã Kitsch qualifica muito bem o gosto que prefere o exagero sentimentalista, melodramático, sensacionalista, valendo-se de chavões e estereótipos inautênticos (HOUAISS, 2001, s. v.). Trata-se, pois, dos produtos culturais de aspecto exageradamente ostensivo, espalhafatoso, sem harmonia, com tendência ao ridículo ou à vulgaridade (HOUAISS, 2001, 'cafona'). Kitsch, nesse sentido, já é o desdobramento metafórico de kitschen, o ato de varrer a lama ou o lixo das ruas, bem como juntar restos ou objetos inúteis (HOUAISS, 2001, s. v.).

59 Opifex rerum, literalmente, o artista das coisas (do mundo).

60 Original: "Pronaque cum spectent animalia cetera terram, / Os homini sublime dedit caelumque tueri / lussit et erectos ad sidera tollere uultus $[\ldots]^{\prime \prime}$. 
lastro do pensamento - as histórias e a música do mundo, em viva metáfora, unindo artes e ciências. E parece existir, não fortuitamente, um fenômeno literário que, de alguma maneira, tenha afixado os mitos nas enormes constelações.

\section{REFERÊNCIAS}

ADORNO, Theodor W.; HORKHEIMER, Max. Dialektik der Aufklärung. Frankfurt: Fischer, 1969 [1944].

ANDRADE, Mario de. Compendio de Historia da Musica. 1. ed. Digitalizado. São Paulo: Cupolo, 1929. Disponível em: http://www.bibliotecadigital.unicamp.br/ document/ code=64516\&opt=1. Acesso em: 25 mar. 2021.

ARISTOTELES; Euclides; Nicomachus; Bacchius; Gaudentius; Alypius. Musici scriptores Graeci. Recognovit prooemis et indice instruxit Carolus Janus. Lipsiae: Teubner, 1895.

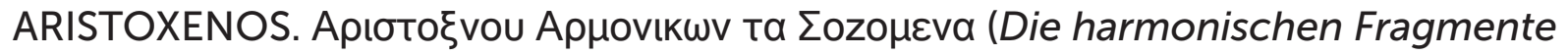
des Aristoxenus). Herausgegeben von Paul Marquard. Berlin: Weidmannsche Buchhandlung, 1868.

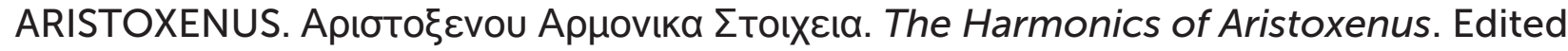
with translation notes; introduction and index of words by Henry S. Macran. Oxford: Clarendon Press, 1902.

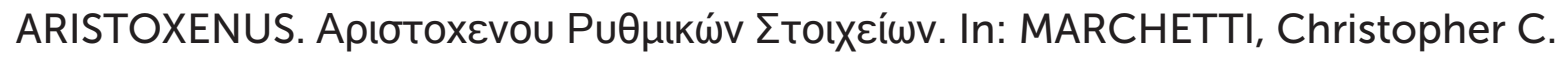
Aristoxenus Elements of Rhythm: Text, Translation, and Commentary with a translation and commentary on POXY 2687. Dissertation (Graduation School-New Brunswick) Rutgers, The State University of New Jersey. New Brunswick, New Jersey, 2009.

ARISTOXENUS, von Tarent. Melik und Rhythmik. Übersetzt und Erläutert durch R. Westphal. Leipzig: Verlag von Ambr. Abel, 1883.

CAPELLA, Martianus. Les noces de Philologie et de Mercure. Livre IX - L'Harmonie. Paris: Les Belles Lettres, 2011.

CHAILLEY, Jacques. L'imbroglio des modes. Paris: LeDuc, 1960.

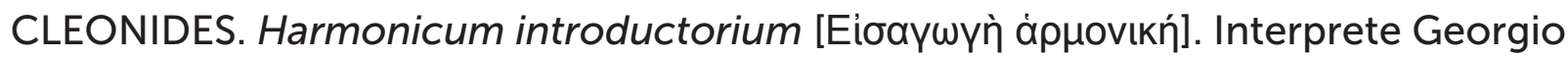
Valla Placentino. Venetiis: Simonem Papiensem dictum Biuilaquam, 1497. 
CLÉONIDE; EUCLIDES. L'introduction harmonique [de Cléonide] et La division du canon [d'Euclide le Géomètre]. Traduction avec commentaire perpétuel de Ch. Emile Ruelle. Paris: Librairie de Firmin Didot et Cie., 1884.

DE MUSICA Scripta Bellermanniana. Bibliotheca Scriptorum Graecorum et Romanorum Teubneriana. Edidit D. Najock. Leipzig: Teubner Verlagsgesellschaft, 1975.

EUSEBIUS [Cesareae]. Preparatio Evangelica. Liber I. United Kingdom: [s. n.], 1903. Disponível em: http://www.tertullian.org/fathers/eusebius_pe_01_book1.htm. Acesso em: 3 maio 2020.

EYCK, Jan van; EYCK, Hubert van. Het lam Gods. 1432. Óleo e madeira, 3.4 x 5.2 m (12 painéis). Catedral de São Bavão, Gante, Bélgica. Disponível em: https://www. sintbaafskathedraal.be/en/history/the-ghent-altarpiece/. Acesso em: 25 fev. 2021.

FULGENTIUS, Fabius Planciades. Opera. Recensuit: Rudolfus Helm. Lipsia: Teubner, 1898.

GALILAEI, Galilaeo. Systema Cosmicum. Augustae Treboc [Strasbourg]: Typis Davidis Havtti, 1635.

GALILEI, Galileo. Siderevs nvncivs. Venetiis: Thomam Baglionum, 1610. Disponível em: www.liberliber.it/biblioteca/g/galilei/sidereus_nuncius/html/sidereus.htm. Acesso em: 4 mar. 2020.

GALILEI, Galileo. Dialogo sopra i due massimi sistemi del mondo Tolemaico, e Copernicano. Fiorenza: Batista Landini, 1632.

GALILEI, Vincentio. Dialogo della mvsica antica, et della moderna. Fiorenza: Giorgio Marescotti, 1581.

GIBSON, Sophie. Aristoxenus of Tarentum and the Birth of Musicology. Edited by Dirk Obbink and Andrew Dyck. New York; London: Routledge, 2005.

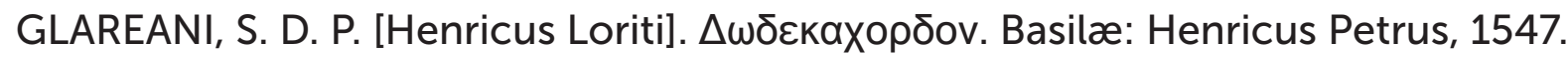

HESÍODO. Os trabalhos e os dias. Trad. e estudo de Luiz Otávio Mantovaneli. São Paulo: Odysseus, 2011. (Coleção Kouros).

HOUAISS, Antônio; VILLAR, Mauro de Salles. Dicionário da Língua Portuguesa. Elaborado no Instituto Antônio Houaiss de Lexicografia e Banco de Dados da Língua Portuguesa S/C Ltda. Rio de Janeiro: Objetiva, 2001. 
KEPLER, loannes. Harmonices Mundi. Austriae: Ioannes Plancus, 1619.

LAERTIUS, Diogenes. Vitarum Philosophorum Libri. Bibliotheca scriptorum Graecorum et Romanorum Teubneriana. Edidit Miroslav Marcovich. Berolini: Walter de Gruyter, 2008.

NEWTON, Isaac. Philosophiae naturalis Principia mathematica. Londini: Jussu Societatis Regiae ac Typis J. Streater, 1686. [Online]. Disponível em: https://cudl.lib. cam.ac.uk/view/PR-ADV-B-00039-00001/1. Acesso em: 20 mar. 2020.

OVIDE. Les Métamorphoses. Text établi et traduit par Georges Lafaye. Paris: Les Belles Lettres, 1928. Tome I (I-V).

PLATON. Oeuvres complètes. Texte établi et traduit par Albert Rivaud. Paris: Les Belles Lettres, 1985. Tome X: Timée - Critias.

PLUTARQUE. De la Musique (Peri Mousikēs). Édition critique et explicative par Henri Weil et Théodore Reinach. Paris: Ernest Leroux, 1900.

PTOLOMEUS. Harmonics. Translation and commentary by Joh Solomon. Leiden; Boston; Köln: Brill, 2000.

QUINTILIANUS, Aristides. De Musica. Edidit Albertus Iahnius. Berolini: S. Calvaryus et sociis, 1882. Libri III.

REMIGIUS, Altisiodorensis. Scriptores ecclesiastici de musica sacra potissimum. Ed. Martin Gerbert, repr. Hildesheim: Olms, 1963 [St. Blaise: Typis San-Blasianis, 1784]. v. 1, p. 63-94. 3 v.

SCHOLIA enchiriadis de arte musica. In: MIGNE, J. P. (ed.). Patrologia cursus completus. Paris: Garnier, 1844-1904. (Series latina, 221 v.)

SUDA. Suidae Lexicon. Ex recognitione Immanuelis Bekkeri. Berolini: typis et impensis Georgii Reimeri, 1854.

THESAURUS MUSICARUM LATINARUM. Bloomington (EUA), School of Music, Indiana University. Disponível em: www.chmtl.indiana.edu/tml/start.html. Acesso em: 10 jun. 2020.

TRENDELENBURG, Fridericus Adolphus. Platonis de ideis et numeris doctrina ex aristotele illustrata. Lipsiae: [s. n.], 1826. 
TROND, Rudolf von [St.]. Die Quaestiones in musica: Ein Choraltraktat des zentralen Mittelalters und ihr mutmasslicher Verfasser Rudolf von St. Trond (1070-1138). Leipzig: Breitkopf und Härtel, 1911. Disponível: http://www.chmtl.indiana.edu/tml/12th/ RUDQUA. Acesso em: 20 mar. 2020. 